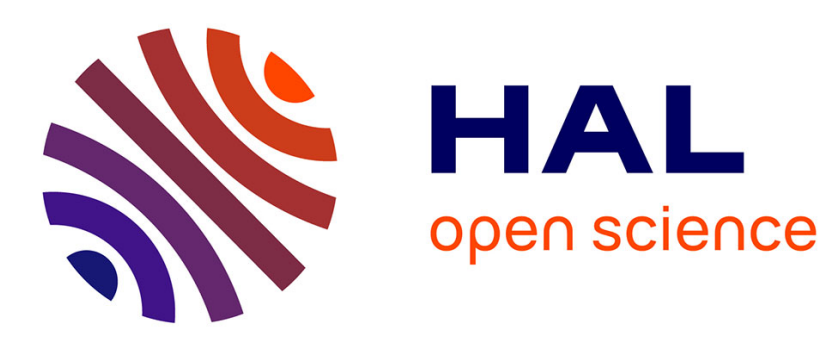

\title{
Conformations of Proteins Adsorbed at Liquid-Solid Interfaces
}

\author{
Sylvie Servagent Noinville, Madeleine Revault
}

\section{To cite this version:}

Sylvie Servagent Noinville, Madeleine Revault. Conformations of Proteins Adsorbed at Liquid-Solid Interfaces. Proteins at Liquid-Solid Interfaces: Principles and Practices, 2006, Principles and Practice 10.1007/3-540-32658-8_6. hal-02159914

\section{HAL Id: hal-02159914 https://hal.science/hal-02159914}

Submitted on 19 Jun 2019

HAL is a multi-disciplinary open access archive for the deposit and dissemination of scientific research documents, whether they are published or not. The documents may come from teaching and research institutions in France or abroad, or from public or private research centers.
L'archive ouverte pluridisciplinaire HAL, est destinée au dépôt et à la diffusion de documents scientifiques de niveau recherche, publiés ou non, émanant des établissements d'enseignement et de recherche français ou étrangers, des laboratoires publics ou privés. 
Principles and practice : Proteins at solid-liquid interfaces, Springer-Verlag, Berlin Heidelberg 2006, pp. 119-150.

DOI : 10.1007/3-540-32658-8_6

\section{Conformations of Proteins Adsorbed at Liquid / Solid Interfaces}

Sylvie Noinville and Madeleine Revault

Laboratoire de Dynamique, Interactions et Réactivité, CNRS-Université Pierre et Marie Curie, UMR 7075, 2 rue Henri Dunant, 94320 Thiais, France.

Phone : 0033149781292

Fax : 0033149781118

$\boldsymbol{e}$ - mail : sylvie.noinville@glvt-cnrs.fr

\section{Contents:}

1 Introduction

2 Experimental Techniques

2.1 High-resolution structure of proteins

2.2 Extent in secondary structure of proteins

2.3 Orientation, localized structural information

2.4 Spatial distribution of proteins in adsorbed layer

2.5 Solvation information

3 Surface Effects on Both Protein Structure and Solvation by ATR-FTIR Technique.

3.1 FTIR spectral analysis

3.2 Proteins in solution

3.3 Surface-induced conformational changes of a 'soft' protein : BSA

3.3.1 Changes in solvation due to adsorption

3.3.2 Adsorption kinetics and conformational changes

3.4 Surface-induced conformational changes of a 'hard' protein : lysozyme

3.4.1 Changes in solvation due to adsorption

3.4.2 Adsorption kinetics and conformational changes

3.5 Folding or unfolding of proteins on hydrophobic supports 
Principles and practice : Proteins at solid-liquid interfaces, Springer-Verlag, Berlin Heidelberg 2006, pp. 119-150.

DOI : 10.1007/3-540-32658-8_6

\begin{abstract}
Non-specific adsorption of globular proteins induces conformationnal changes depending both on the nature of the sorbent phase and on the structural stability of the protein. Because proteins can adopt various flexible three-dimensional structures under external perturbation, the surface contact with a sorbent phase can stabilize or not different conformers which will influence the adsoprtion and desorption kinetics. Biophysical techniques such as Fourier Transform Infrared (FTIR) and Circular Dichroïsm (CD) spectroscopies enable the determination of the extent in secondary structures of the adsorbed protein at aqueous/solid interface. Based on practical viewpoints of protein adsorption, we review findings obtained in a wide range of sorbent phases such as mineral particles, colloidal systems, planar surfaces chemically modified by polymers or self-assembled monolayers. We lay emphasis on the importance to obtain both structural and solvation insights during adsorption by the combined NH/ND isotope exchange and ATR-FTIR techniques. We present illustrative cases of adsortpion of proteins of low and high structural stabilities, respectively Bovine serum albumin and lysozyme on either hydrophobic or hydrophilic supports.
\end{abstract}


Principles and practice : Proteins at solid-liquid interfaces, Springer-Verlag, Berlin Heidelberg 2006, pp. 119-150.

DOI : 10.1007/3-540-32658-8_6

\section{Introduction}

Over the past few years, numerous studies have aimed at understanding which driving forces govern protein adsorption at liquid/solid interfaces (Norde 1998, 2000). Spontaneous adsorption of protein molecules onto a solid sorbent will occur if the Gibbs energy of the system decreases. The enthalpic energy results from electrostatic mechanism and H-bonding interactions while the entropic contribution comes from the change of the initial ordered structure of the adsorbed protein as well as the rearrangement of water molecules and counterions at the interface. The protein folding is well known to be a highly cooperative process in solution. The denaturation of the globular proteins corresponds to a Gibbs energy in the 20 to $100 \mathrm{~kJ} / \mathrm{mol}$ range, which is equivalent to the energy required for the disruption of 1 to 8 hydrogen bonds. Cooperative interactions do not involve the entire protein molecule, so that some partially folded conformations exist in solution as a result of local rather than global unfolding (Radford et al. 1992). When a denaturation process occurs in solution, the conformational entropy is offset by the enthalpy gain and the entropy loss due to the rearrangement of water molecules around the de novo external amino-acid distribution of the protein. When adsorbed onto a solid support, one external side of the protein molecules previously surrounded by water molecules is then in contact with the sorbent surface. Consequently the mechanism of surface-induced conformational changes may be quite different from the one causing protein unfolding in solution induced by denaturant addition or by heating. Recently, a high rate of partial unfolding of $\alpha$-Lactalbumin adsorbed on polystyrene (around $74 \mathrm{sec}^{-1}$ ) was determined by nuclear magnetic resonance (NMR) experiments compared to the lower rate of pH-induced global unfolding (Engel et al. 2004). Circular dichroïsm (CD) studies have shown the difference between the heat-induced unfolding of Immunoglobulin and the surface-induced process when the protein is adsorbed on Teflon particles (Vermeer et al. 1998).

One common feature of the structure of the globular proteins is that the polar residues are located on the external surface and that most of the apolar amino acids are buried in the protein core. However, a significant fraction of the external surface of the protein molecule is composed of hydrophobic patches, which account for up to 40 to $50 \%$ (Branden and Tooze 1991; Dill et al. 1995; Richards 1977). If the external surface of the protein is polar as for the sorbent phase, some hydration water molecules are retained to solvate the protein 
Principles and practice : Proteins at solid-liquid interfaces, Springer-Verlag, Berlin Heidelberg 2006, pp. 119-150.

DOI : 10.1007/3-540-32658-8_6

charged residues and the surface charges. If the protein surface is rather apolar and the sorbent phase polar or vice-versa, a dehydration of the protein-solid interface could occur. In case of hydrophobic character for both the protein surface and the solid support, structural changes of the proteins as well as variations in solvation states modify the entropy of the overall system (Boulkanz et al. 1997; Dorsey and Dill 1989; Gilpin 1993; Lu J.R. et al. 1998; Norde 1998). In some cases, the adsorption on hydrophobic supports induces a conformational change large enough to cause an average increase of the protein hydration (Boulkanz et al. 1995; McNay and Fernandez 1999). For both hydrophobic and hydrophilic supports, protein solvation and structural changes also depend on the $\mathrm{pH}$ and the ionic strength of the liquid phase as these parameters indirectly influence the entropic forces (Baron et al. 1999; Giacomelli C.E. et al. 1999b; Haynes and Norde 1995; Kondo A. et al. 1991; Quiquampoix et al. 1993; Servagent-Noinville et al. 2000; Su et al. 1998b).

Of course, the adsorption process depends strongly on the chemical and electrical properties of the sorbent phase. Many studies concerning the protein adsorption onto polar charged support show that the major driving force is of coulombic nature (Gill et al. 1994; Lesins and Ruckenstein 1989; Quiquampoix et al. 1995; Servagent-Noinville et al. 2000; Su et al. 1998b). The design of electrostatically neutral surfaces is sought for their ability to reduce protein adsorption. In that case, the different hydration properties lead to repulsive hydration forces at close approach responsible for the inhibited adsorption (Herrwerth et al. 2003; Jeon S. I. et al. 1991). On hydrophobic supports, adsorption is driven by the reduction of interfacial energetics concomitant with the replacement of water molecules by the adsorbed proteins (Vogler 1998).

Besides these interactions between a single protein molecule and the solid phase, proteinprotein interactions of either electrostatic or hydrophobic origins may also influence the accumulation of proteins at the liquid/solid interface. For both hydrophobic and hydrophilic supports, all these parameters govern the specific orientation and the structure of the protein molecules inside the adsorbed layer (Malmsten 1998; Wahlgren M. et al. 1998). One approach to gain insight in the impact of hydrophobic or electrostatic interactions on the adsorption mechanism is to study protein adsorption on molecularly well-defined surfaces such as self-assembled monolayers (SAMs) on gold or silicon (Mrksich et al. 1995; Silin et al. 1997). Surface plasmon resonance (SPR) studies have shown that the propensity of SAMs of gradient wettabilities to adsorb proteins is related to the interfacial free energy of these surfaces despite important exceptions (Sigal et al. 1998). Non-charged hydrophilic 
Principles and practice : Proteins at solid-liquid interfaces, Springer-Verlag, Berlin Heidelberg 2006, pp. 119-150.

DOI : 10.1007/3-540-32658-8_6

surfaces such as $\mathrm{OH}$-terminated SAMs are generally correlated with low protein retention (Silin et al. 1997; Tengvall et al. 1998). Although ethylene glycol terminated SAMs are known to be highly resistant to protein adsorption, these supports are characterized by intermediate wettabilities (Herrwerth et al. 2003; Ostuni et al. 2001). The correlation between macroscopic surface property such as wettability and protein adsorption seems to be restrictive to the choice of model proteins under investigation. However a mean to study the influence of one single isolated hydrophobic end-group on the protein adsorption is provided by mixing two types of end-groups whose one is a known repelling moiety to build well-controlled hydrophobic patches inside the SAMs (Ostuni et al. 2003).

In general, the adsorption of proteins from aqueous solutions onto a solid support occurs via three major steps: (i) transport of protein molecules from the bulk to the interface, (ii) contact of the protein molecules to the solid surface and (iii) conformational changes of the protein molecules during adsorption. Because the structural changes of the protein is kinetically controlled, accurate knowledge of the adsorption kinetics is of great importance. Most of the general patterns governing the kinetics of protein adsorption have been described in previous reviews (Brash 1996; Malmsten 1998; Ramsden 1998).

The structural rearrangement caused by the direct contact with the sorbent phase enables the existence of different conformers, which result from the way local unfolding could propagate along the entire molecule depending from the intrinsic stability of the protein. In the case of strong protein-sorbent interactions, non-equilibrium states could be retained at the liquid/solid interface. Hence protein adsorption could appear like an irreversible process depending on different time scales. Moreover, structural changes of the protein involving more than $10 \%$ of the polypeptide backbone are generally associated to a spreading phenomenon allowing a greater number of contacts with the sorbent phase (Jeon J.S. et al. 1994; Noinville S. et al. 2002; Su et al. 1998b). Hence, the desorption of even partially unfolded proteins becomes difficult. Besides, the protein molecules by spreading over the sorbent phase delay or prevent from the attachment of additional protein molecules. The adsorption rate and the conformational changes could depend on the surface coverage insofar as the adsorption takes place at a more and more modified interface. As a consequence, the layer of adsorbed proteins could be composed of a heterogeneous distribution of adsorbed conformers (Pitt and Cooper 1986; Zoungrana et al. 1997). A 
Principles and practice : Proteins at solid-liquid interfaces, Springer-Verlag, Berlin Heidelberg 2006, pp. 119-150.

DOI : 10.1007/3-540-32658-8_6

general trend in adsorption of globular proteins is to distinguish between two classes associated to distinct adsorption behaviour in relation with their structural stabilities (Arai and Norde 1990; Kondo A. et al. 1991; Norde 1998). On one hand, the so-called 'soft' proteins with low structural stability depict protein molecules with a high tendency to denature upon adsorption even if the sorbent phase is weakly attractive (Table 1). On the other hand, hard proteins tend to adsorb less strongly on hydrophilic supports unless attractive electrostatic interactions prevail (Table 2). These hard proteins generally undergo minor conformational changes except when adsorbed onto hydrophobic supports. Recently, dynamic Monte Carlo simulations have corroborated the relationship between the nativestate structural stability of the protein and its adsorption behaviour by computing the changes in the system entropy (Liu and Haynes 2005). One strategy to change the protein structural stability is to perform site-directed mutagenesis. The substitution of one single residue in the primary sequence of the protein provides mutants of different intrinsic stability and adsorption behaviour (Brash 1996; Malmsten et al. 2003). McGuire et al. studied protein adsorption of wild type of bacteriophage T4 lysozyme and various mutants on flat silica surfaces (McGuire et al. 1995). The variant of the lower structural stability displayed the slowest adsorption kinetics while it undergoes the largest unfolding of $\alpha$ helices as shown by CD studies on silica nanoparticles (Billsten et al. 1998). The structural stability of the protein is a key factor in determining the rate of conformational changes for different mutants of human carbonic anhydrase I and II (Lundqvist et al. 2004; Malmsten et al. 2003). Recently, the rate of the surface-induced conformational change of the HCA variants is indeed affected by the stability of the variant but the average conformation of the final adsorbed state is not (Karlsson et al. 2005). Wild type recombinant interferon $\gamma$ and its Asp25-mutant have different adsorption behaviour as studied on hydrophobic supports by Fourier transform infrared spectroscopy (FTIR) analysis (deCollongue-Poyet et al. 1996). The adsorbed amount of the mutant is lower than that of the wild type protein. The contact with the hydrophobic support entails a different increase in the amount of polar helices and bend domains in mutant and wild types in respect with the conformation in solution. However, this mutation of one single residue does not change the protonation state of the interferon but induces a local change in the packing of the $\alpha$-helices. One drawback of sitedirected genetic engineering or chemical modification used to modulate protein hydrophobicity or protein net charge is to alter also the structure of the protein under study (van der Veen et al. 2004). 
Principles and practice : Proteins at solid-liquid interfaces, Springer-Verlag, Berlin Heidelberg 2006, pp. 119-150.

DOI : 10.1007/3-540-32658-8_6

Due to the peculiar behaviour of protein molecules, the adsorption of protein to solid surfaces is a result of a large number of parallel and consecutive reaction steps rendering difficult the study of kinetics and thermodynamics of the protein/solid system (Fang and Szleifer 2001). Models concerning the conformational changes of adsorbed proteins have been proposed for fitting experimental kinetics studies (Kridhasima et al. 1993; Pantazaki et al. 1998; Soderquist and Walton 1980). However, the main difficulty encountered in most theories of protein adsorption is to choose at which level to depict the protein/solid interface. As a starting point, the macroscopic description is to consider the globular protein as a rigid sphere with a net electrostatic charge on a plane surface (Roth and Lenhoff 1993). Some colloidal models account for conformational changes upon adsorption considering the existence of different adsorbed conformers such as a folded state and a fully denatured state of the adsorbed protein (Van Tassel et al. 1998). A more sophisticated model is to depict the map of the protein surface, the distribution of positive and negative charges and the surface polarity. This methodology yields better predictions of interactions between like-charged proteins and surfaces (Asthagiri and Lenhoff 1997). The more sophisticated approach is to depict the protein using its three-dimensional structure. Early simulation studies of protein adsorption based on its full atomistic description have reported calculated energetics as a function of the orientation and the separation distance of the protein towards the surface in the case of uniformly charged support (Yoon and Lenhoff 1992) or a polymer surface represented atomistically (Noinville V. et al. 1995; Roush et al. 1994). Most recent studies are focussed not only on interaction energy or adsorbed amount but also on orientation of adsorbed proteins or peptides (Noinville S. et al. 2003; Zhou et al. 2003). Monte Carlo simulations of adsorption of immunoglobulins on charged surfaces lay emphasis on the dependence of the protein orientation versus surface charge density as previously shown experimentally (Zhou et al. 2003). A preferred orientation for the antibodies on the charged surface is determined when electrostatic interactions prevail over the hydrophobic ones. In all these studies, the aqueous media is described as a continuous dielectric medium. A simulation study of a small peptide of 5 residues is reported with explicit water molecules, demonstrating their orientational structure at a peptide/non polar solid interface (Bujnowski and Pitt 1998). 
Principles and practice : Proteins at solid-liquid interfaces, Springer-Verlag, Berlin Heidelberg 2006, pp. 119-150.

DOI : 10.1007/3-540-32658-8_6

\section{Experimental Techniques}

Short overview of experimental methods currently used to follow adsorption kinetics is given in literature (Kurrat et al. 1994). In this section, we will focus on biophysical methods that reveal the structural changes upon adsorption approaching the molecular scale. Then we will present methods allowing combined kinetics and structural data. Finally, we will detail methods that provide information about distribution, orientation and solvation of the adsorbed proteins.

No experimental means of direct determination of protein structure is currently available at an atomistic scale when the protein is in contact with a solid surface. However, many progresses have been made to gain structural insight at various aqueous/solid interfaces. In general, the biophysical methods allowing the protein structure determination fall into two categories: one giving high-resolution structural characterization such as $\mathrm{x}$-ray crystallography, neutron diffraction and NMR spectroscopy, and the second one giving the extent of secondary structure or information on the tertiary structure using FTIR or CD techniques.

\subsection{High-resolution structure of proteins}

Apart from x-ray crystallography and neutron diffraction dedicated for crystallized proteins, all other biophysical techniques well suited for proteins in solution could be adapted to interfacial analysis provided more or less limitations due to the heterogeneous character of the protein/sorbent phase under study. Recent progresses in NMR spectroscopy allow determining structures of small membrane proteins (up to $20 \mathrm{kDa}$ ) in detergent micelles (Booth et al. 2004; Tamm et al. 2003). This opens a new window to study the dynamics of proteins at aqueous/fluid interface. A first high-resolution structural characterization using solid-state NMR was carried out for statherin, a protein of around $5 \mathrm{kDa}$, adsorbed on an inorganic support such as hydroxyapatite in the hydrated and lyophilized states (Long et al. 2001), enlightening the role of water in stabilizing the helical structure of the adsorbed peptide. A combined study by CD and NMR spectroscopies has shown the localized $\alpha$-helix unfolding of small peptides adsorbed at an aqueous/colloidal interface (Read and Burkett 2003). 
Principles and practice : Proteins at solid-liquid interfaces, Springer-Verlag, Berlin Heidelberg 2006, pp. 119-150.

DOI : 10.1007/3-540-32658-8_6

\subsection{Extent in secondary structure of proteins}

The practical limitations encountered by the high-resolution structural techniques such as isotope labelling, size of the protein/colloid system, size of the protein itself render the methods such as CD and vibrational spectroscopies still attractive. These low-resolution techniques provide global estimation of the secondary structures ( $\alpha$-helix, $\beta$-sheet or random coil) without specifying the local region involved in the conformational transition. The latter techniques are suitable to study proteins at liquid-solid interfaces in more or less restricted conditions. For CD spectroscopy, limitations come from the significant scattering of the wavelength of interest due to the size of the sorbent particles. The use of silica nanoparticles of diameter size not exceeding $20 \mathrm{~nm}$ has been specifically developed for CD experiments (Billsten et al. 1998). Adsorption of globular proteins of different structural stabilities has been studied by CD on charged silica nanoparticles (Giacomelli Carla E. and Norde 2001; Kondo A. et al. 1991; Kondo A. and Fukuda 1998). These studies have shown that the largest conformational changes are observed for the adsorption of the less stable proteins such as BSA, myoglobin or hemoglobin. In contrast the more rigid proteins such as cytochrome c, immunoglobulin G (IgG) and Ribonuclease (RNase) characterized by their low adiabatic compressibility are less unfolded by the contact with the hydrophilic surface (Table 2).

Partially hydrophobic supports could be used for CD experiments by modification of silica particles by polymer silane coupling agents (Kondo Akihiko et al. 1996) or by the use of Teflon latex nanoparticles (Giacomelli C. E. and Norde 2003; Zoungrana et al. 1997). Recent CD measurements of protein adsorption on silica nanoparticles of various diameters combined with NMR have shown that the amount and the secondary structures of the adsorbed protein depend on the particle curvature (Lundqvist et al. 2004).

FTIR spectroscopy reveals not only changes in the global secondary structures of proteins (Byler and Susi 1986; Surewicz et al. 1993) but also allows the determination of the average solvation states by H/D isotope exchange as detailed later on (Mitchell et al. 1988; Muga et al. 1991) and can quantify the protonation states of the aspartate and glutamate side chains (Chirgadze et al. 1975). Transmission-FTIR spectroscopy is still used for direct comparison between a protein in solution and the same protein adsorbed on various types of solid particles such as chromatographic supports (Boulkanz et al. 1997; Soderquist and Walton 1980) or clay minerals (Revault et al. 2005; Servagent-Noinville et al. 2000). The only limitation is a particle size not exceeding $10 \mu \mathrm{m}$. Conformational changes could be 
Principles and practice : Proteins at solid-liquid interfaces, Springer-Verlag, Berlin Heidelberg 2006, pp. 119-150.

DOI : 10.1007/3-540-32658-8_6

correlated with chromatographic retention times in the case of serum albumin and interferons (Boulkanz et al. 1995; Pantazaki et al. 1998).

A strategy to study both adsorption kinetics and protein structural transition by FTIR is to use Attenuated Total Reflection mode at the liquid/planar solid interface (Ball A. and Jones 1995; Chittur 1998; van-Straaten and Peppas 1991). So as to obtain a large variety of sorbent phase, many modification of the ATR crystal plate could be obtained either by deposition of lipids (Sharp et al. 2002) or polymers (Green et al. 1999; Lenk et al. 1989; Sukhishvili and Granick 1999) or by chemical grafting of self-assembled monolayers (Cheng et al. 1994; Noinville S. et al. 2003). Adsorption kinetics may be monitored by measuring the time dependent Amide-band increase in a flow system or in stationary conditions (Chittur et al. 1986; Jeon J. S. et al. 1992). The earliest ATR-FTIR experiments were devoted to the real-time adsorption kinetics of proteins of interest to biomaterials including immunoassays, protein chromatography, biosensors and biocatalysis (Cheng et al. 1994; Fu et al. 1993; Lenk et al. 1989; Müller et al. 1997; Ong et al. 1994). For instance, adsorption of immunoglobulin $\mathrm{G}$ (IgG) onto different supports was largely studied in regard with both adsorbed amount and structure to ensure antigen binding (Giacomelli Carla E. et al. 1999a). The Y-shaped IgG molecules are composed of two $F_{a b}$ segments and one $F_{c}$ domain. The $\mathrm{F}_{\mathrm{ab}}$ segments containing the binding sites show a different stability from the whole IgG molecules. The less structurally stable $F_{c}$ fragment is more readily adsorbed than the $F_{a b}$ ones affecting the orientation of the adsorbed $\operatorname{IgG}$ (Buijs et al. 1996).

\subsection{Orientation, localized structural information}

Structural parameters of the adsorbed protein layers may be obtained by using intrinsic fluorescence spectroscopy on chromatographic supports (Oroszlan et al. 1990), on silica and chemically modified silica slides (Buijs and Hlady 1997; Iwamoto et al. 1985). Furthermore fluorescence polarization measurements enable the study of the orientation and the rotational mobility of adsorbed proteins (Bos and Kleijn 1995; Tronin et al. 2002). Side-on or end-on orientations of lysozyme on hydrophobic and hydrophilic surfaces were deduced from kinetic measurements using TIRF (Wertz and Santore 2002). In some cases, polarized ATR measurements may allow the determination of the interfacial orientation of the protein in the adsorbed layer and have been mainly reported to the analysis of predominantly helical proteins inserted in lipid films (Frey and Tamm. 1991; Houbiers et al. 2001; Martin et al. 2003). Molecular order of the whole protein is generally inferred from the measured 
Principles and practice : Proteins at solid-liquid interfaces, Springer-Verlag, Berlin Heidelberg 2006, pp. 119-150.

DOI : $10.1007 / 3-540-32658-8 \_6$

dichroïc ratios obtained for the stereoregular $\alpha$-helical domains of the protein (Martin et al. 2003; Methot et al. 1996). On solid support, molecular orientation of a $\alpha$-helical peptide could be determined thanks to the specific hydrophobic interaction between the amphipathic peptide with the $\mathrm{CH}_{3}$-terminated SAM (Noinville S. et al. 2003). Interpretation of polarized Infrared data seems to be more difficult for the $\beta$-sheeted structure (Chittur 1998).

\subsection{Spatial distribution of proteins in adsorbed layer}

Neutron reflectrometry in combination with water contrast variation can probe interfacial layer thickness with a resolution of a few angstroms and has provided information on mean structural conformations for globular protein layers at the aqueous/solid interface (Follows et al. 2004; Lu J. R. et al. 2005; Marsh et al. 1999; Tiberg et al. 2001).

Direct imaging methods like Atomic Force Microscopy (AFM), Surface Force Microscopy (SFM), and Scanning Tunnelling Microscopy (STM) are well suited for probing the protein morphology on solid supports (Haggerty and Lenhoff 1993a). Most studies of the adsorption of proteins by AFM were carried out on dry-sample imaging methods (Ortega-Vinuesa et al. 1998). The number of in situ adsorption at liquid/solid interface is much more limited (Kim et al. 2002). These techniques provide complementary information such as lateral distribution of protein molecules on surfaces and could also perform direct measurements of forces between the adsorbent phase and a single protein (Claesson et al. 1995). With SFM, measurements of forces and distances between two proteins coated on mica surfaces have been evaluated for bovine serum albumin (BSA) (Perez and Proust 1987) and for lysozyme (Haggerty and Lenhoff 1993b). Many AFM studies by using self-assembled monolayers as chemically patterned surfaces track the effect of the chemical properties as well as the surface topology of the sorbent support on the conformation of the individual protein molecules in the adsorbed layer ( $\mathrm{Li}$ et al. 2003; Marchin and Berrie 2003; Patel et al. 1998; Wadu-Mesthrige et al. 2000).

\subsection{Solvation information}

Upon exposure to $\mathrm{D}_{2} \mathrm{O}$, the amide proton of the protein backbone will exchange with the solvent deuterium. The hydrogen/deuterium exchange rate depends on $\mathrm{pH}$, temperature and on the structural environment of the amide proton (Gregory and Lumry 1985). Factors such as steric inaccessibility to solvent, local charge distributions and internal hydrogen bonding will slow down the rate of amide proton exchange so that the kinetics of $\mathrm{D}_{2} \mathrm{O}$ diffusion 
Principles and practice : Proteins at solid-liquid interfaces, Springer-Verlag, Berlin Heidelberg 2006, pp. 119-150.

DOI : 10.1007/3-540-32658-8_6

inside the protein core probes the accessibility of the solvent into random or structured internal domains and thus can give information on the protein tertiary structure. NMR or mass spectrometry and isotope exchange techniques can be used to probe tertiary structure or conformational stability of proteins (Huyghues-Despointes et al. 2001). For instance, these techniques were carried out for lysozyme before and after elution from reversed chromatographic phases (McNay and Fernandez 1999; Tibbs Jones and Fernandez 2003). The mass increase of the protein resulting from the hydrogen/deuterium exchange could be measured by mass spectrometry. For example, localized changes in the structural stability of myoglobin upon adsorption onto nanometer-sized silica particles were studied with isotopic exchange mass spectrometry (Buijs et al. 2003).

Exchange rate measurements could be performed directly on adsorbed proteins by infrared spectroscopy from the decrease of the so-called Amide II absorption band as a function of pH (Servagent-Noinville et al. 2000). The Amide II absorption band corresponds to the bending motions of the residual CONH groups resulting from the incubation of the protein in deuterated buffer. Two-dimensional (2D) FTIR spectroscopy developed by Noda (1989) (Noda 1989) could be used to enhance the spectral resolution of both Amide I and II bands of proteins and to allow assignments of the conformation-sensitive component bands (Nabet and Pézolet 1997). 2D-FTIR spectroscopy combined with isotopic exchange has revealed the assignment of the exchanging amide proton to changes in protein secondary structure induced by a ligand binding (Meskers et al. 1999). Surface-induced conformational changes of cytochrome $\mathrm{c}$ and of antimicrobial peptides were evidenced by the use of 2D-FTIR spectroscopy (Lecomte et al. 2001; Noinville S. et al. 2003).

\section{Surface Effects on Both Protein Structure and Solvation by ATR-FTIR Technique.}

We investigate protein adsorption on three types of planar solid supports classified in hydrophilic or hydrophobic model surfaces. The planar model supports were obtained by modifying the native silica surface of the ATR crystal with $\omega$-functionalized alkylsilanes bearing at the end a bromo or a methyl group. The chemical transformation of the bromoterminated SAMs enables to obtain a polar aminated support (Noinville S. et al. 2003). Among the two hydrophilic supports, the native silica surface of the ATR crystal is used as a 
Principles and practice : Proteins at solid-liquid interfaces, Springer-Verlag, Berlin Heidelberg 2006, pp. 119-150.

DOI : $10.1007 / 3-540-32658-8 \_6$

negatively charged surface while the $\mathrm{ND}_{2}$-terminated SAMs, still not protonated at $\mathrm{pD} 7.5$, is considered as neutral support. We will present infrared results performed with hydrosoluble proteins such as BSA and lysozyme chosen as illustrative cases of adsorption of respectively 'soft' and 'hard' proteins on the three different types of supports. Then we will present results enlightening the role of the protein nature and size specifically during adsorption on hydrophobic supports.

Before reviewing the results concerning the surface-induced conformational changes, we introduce the specific processing of infrared spectra of proteins.

\subsection{FTIR spectral analysis}

Infrared spectra of proteins in aqueous media exhibit nine characteristic absorption bands, which represent different vibration modes of their peptide moiety. Among all the amide vibrational modes, the most frequently used in studies of protein secondary structure is the amide I band. This vibrational mode in the $1600-1700 \mathrm{~cm}^{-1}$ spectral range corresponds to the stretching mode of the peptide carbonyls. This broad infrared absorption band, sensitive to the protein conformation, is composed of multiple component bands, whose wavenumber depends on whether the peptide carbonyls are hydrogen bonded to other peptide units, or to side-chains, or to solvent. Each component band could be assigned to a different structural element such as $\alpha$-helix, $\beta$-sheet, or 'free' peptide groups located in random hydrophobic or polar domains. Spectral correlation with secondary structure in the amide I spectral region is well documented on model polypeptides (deLozé and Fillaux 1972; Tsuboi 1964) and on a large number of globular proteins (Byler and Susi 1986; Goormaghtigh et al. 1994; Kalnin et al. 1990; Krimm and Bandekar 1986).

Because the broad amide I band is made of overlapping component bands, the techniques of resolution enhancement are necessary to extract the useful structural information from the infrared spectra of proteins. The main mathematical methods used to analyze infrared spectra of proteins are self-deconvolution or second-derivative processing and curve-fitting, and are well described in literature (Dong et al. 1990; Dousseau and Pézolet 1990; Surewicz et al. 1993).

Prior to the infrared analysis, the subtraction of water contribution must be undertaken. Even if many algorithms are now available to subtract water contribution from the infrared spectra of proteins, this protocol should be used with caution concerning infrared spectra of adsorbed proteins. Indeed, the adsorption process could induce a change in solvation of both 
Principles and practice : Proteins at solid-liquid interfaces, Springer-Verlag, Berlin Heidelberg 2006, pp. 119-150.

DOI : $10.1007 / 3-540-32658-8 \_6$

the proteins and the solid support. As a result, the water molecules present at the interface could be more or less involved in hydrogen bonding which shift the broad water contribution band and render difficult the subtraction of their infrared contribution (Giacomelli Carla E. et al. 1999a). The main advantage to perform infrared analysis of proteins in $\mathrm{D}_{2} \mathrm{O}$ is to allow a direct comparison between the solvated state and the adsorbed state of the protein. Concerning the determination of secondary structure, a few minutes of incubation of the protein in deuterated medium is enough to shift the Amide I band of 2 to $10 \mathrm{~cm}^{-1}$. Assignments of component bands of the so-called Amide I' band are reported in different works on globular proteins (Chirgadze and Brazhnikov 1974; Goormaghtigh et al. 1994). The great advantage is the shift of the disordered component band of Amide I centered at $1650 \mathrm{~cm}^{-1}$ in $\mathrm{H}_{2} \mathrm{O}$ to $1640 \mathrm{~cm}^{-1}$ in $\mathrm{D}_{2} \mathrm{O}$, whereas the component bands relative to ordered structures ( $\alpha$-helices, $\beta$-sheets) are less affected upon deuteration (Wantyghem et al. 1990).

In our procedure, the curve fitting is performed on both the Amide I' and Amide II spectral regions and calculated as a linear combination of individual band-components by iterative adjustments of only heights of the components, the other parameters like profiles, widths and wavenumbers being fixed. Then the fractional areas of the band-components are assumed to represent percentages of the different types of ordered or random domains of the protein. Since FTIR spectra and mathematical decompositions are all run in the same way, the resulting difference of the spectral analyses between the adsorbed state and the state in solution reveals semi-quantitatively the structural transition upon adsorption (Baron et al. 1999; Noinville S. et al. 2002; Revault et al. 2005; Servagent-Noinville et al. 2000; Wantyghem et al. 1990).

Moreover, using deuterated media enables to follow the NH/ND exchange of the all amide protons of the protein backbone by the decrease of the Amide II band. Since the NH/ND exchange rate slows down with the strength of hydrogen bonding involved in stereoregular structures, it is possible to extract information on the protein stability, as well.

\subsection{Proteins in solution}

A protein may adopt in solution various structures with more or less subtle differences, depending on temperature, protein concentration, $\mathrm{pH}$, ionic strength or addition of cosolvent or lipids. The rapid FTIR analysis is well suited to probe the extent in secondary 
Principles and practice : Proteins at solid-liquid interfaces, Springer-Verlag, Berlin Heidelberg 2006, pp. 119-150.

DOI : 10.1007/3-540-32658-8_6

structures of the protein in the solution state used as reference for the adsorption experiments.

As an illustration, the lists of the Amide I' component bands identified via second-derivative methods are reported in Table 3 for BSA and lysozyme in deuterated phosphate buffer (Noinville S. et al. 2002; Servagent-Noinville et al. 2000). For $\alpha$-helical proteins such as BSA, our infrared spectroscopic analysis distinguishes a major group of regular helices giving a component band at $1651 \mathrm{~cm}^{-1}$ from a minor group of irregular helices at $1660 \mathrm{~cm}^{-}$ 1. This latter component band at higher wavenumber is attributed to helices packed in a more hydrophobic environment (Dousseau and Pézolet 1990; Rothshild and Clark 1979). Our results presented in Table 3 show that BSA is stabilized by a large amount of $\alpha$-helical domains representing $53 \%$ of the overall polypeptide backbone at $\mathrm{pD} 7.5$. X-ray structure of homologous serum albumin such as HSA gives approximately $67 \%$ of $\alpha$-helix (Carter and Ho 1994). The stability of the secondary structure of BSA is known to depend on $\mathrm{pH}$. Previous infrared analysis based on the same spectral decomposition predicted a $61 \%$ helix content for BSA at pD equal to its isoelectric point (Servagent-Noinville et al. 2000). The intramolecular hydrogen bonds, visible at $1630 \mathrm{~cm}^{-1}$ involving approximately $23 \%$ of the peptide groups correspond to bent domains in the BSA backbone. This is in agreement with secondary structure predictions estimating that around $23 \%$ of the structure in extended chain conformation would be predicted as $\beta$-strand (Carter and Ho 1994). In the random coil domains, BSA presents $13 \%$ of its carbonyl groups from peptide bonds involved in hydrogen bonding with water $\left(1640 \mathrm{~cm}^{-1}\right)$. Other random coil domains represent $12 \%$ of the BSA backbone and self-associated domains only 2\% (Table 3). The component band located in the $1610-1620 \mathrm{~cm}^{-1}$ spectral region appears mainly after denaturation of a protein, as reported for cytochrome c (Muga et al. 1991) and for lectins (Wantyghem et al. 1990). This low wavenumber component is attributed to peptide $\mathrm{CO}$ involved in intermolecular $\beta$ sheets or in self-association or aggregation, and is often found in amyloid peptides or in oligomeric prions (Revault et al. 2005; Sokolowski et al. 2003).

While the crystal structure of lysozyme reveals that $28 \%$ of the residues are in $\alpha$-helical conformation (Wilson et al. 1992), the FTIR analysis gives $34 \%$ of $\alpha$-helix content. The crystallized lysozyme also contains a relatively high amount of 310 -helix (11\%). If we assume that the absorption frequencies of $3_{10}$-helix and $\alpha$-helix are closed enough to form 
Principles and practice : Proteins at solid-liquid interfaces, Springer-Verlag, Berlin Heidelberg 2006, pp. 119-150.

DOI : 10.1007/3-540-32658-8_6

only one component band at around $1650 \mathrm{~cm}^{-1}$, the helical content in lysozyme reaches 39

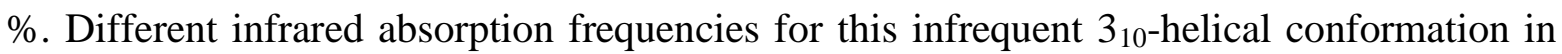
globular proteins have been found in literature. It has been proposed that $3_{10}$-helix adsorbs at lower frequency than $\alpha$-helices in $\mathrm{D}_{2} \mathrm{O}$ solutions due to their tighter geometry (Prestrelski et al. 1991) rather than at $1665 \mathrm{~cm}^{-1}$ as previously reported (Krimm and Bandekar 1986). The amount in hydrogen-bonded peptide $\mathrm{CO}$ with water molecules found for lysozyme is rather large (around $27 \%$ ). Following the attribution given by Prestrelski et al, some of this $\mathrm{H}$ bonded peptide $\mathrm{CO}$ absorbing at $1640 \mathrm{~cm}^{-1}$ would be in fact involved in 310 -helix. Concerning $\beta$-structure, only $6 \%$ of the residues in the crystalline state of lysozyme are in $\beta$-strands (Wilson et al. 1992), whereas $11 \%$ of H-bonded peptide groups involved in $\beta$ structure are found by FTIR. Some of the peptide carbonyls considered as turns (35\%) or as bends $(4.6 \%)$ in the secondary structure from the $\mathrm{x}$-ray data are interleaved between peptide $\mathrm{CO}$ involved in $\beta$-strands so that they could either participate to the infrared band at 1630 $\mathrm{cm}^{-1}$ if hydrogen-bonded or to the infrared band attributed to peptide CO involved in loops in polar environments at $1670 \mathrm{~cm}^{-1}$ if non-hydrogen bonded (deLozé et al. 1978).

\subsection{Surface-induced conformational changes of a 'soft' protein : BSA}

Generally, proteins with low structural stability tend to adsorb on both hydrophobic and hydrophilic support via a gain in conformational entropy. In the case of hydrophilic support, the soft proteins undergo more severe unfolding of the ordered structure because of a stronger increase in conformational entropy to compensate repulsive coulombic interaction on electro statically repelling surface.

\subsubsection{Changes in solvation due to adsorption}

The NH/ND exchange undergone by BSA in response to exposure to the deuterated buffer is monitored by the Amide II/Amide I' ratio measurements and is shown in Figure 1. At time zero, the exchange always involved the fully $\mathrm{CONH}$ protein. Within 10 minutes of incubation in deuterated buffer, $70 \%$ of the peptide CONH in BSA become COND, corresponding to the fast-exchangeable peptide protons of the readily water-accessible external residues of the protein. It takes more than 2 hours to further exchange $12 \%$ of peptide NH of the BSA backbone. These slower-exchanging protons are located in more internal domains or in the more hydrophobic secondary structures of the protein (Gregory 
Principles and practice : Proteins at solid-liquid interfaces, Springer-Verlag, Berlin Heidelberg 2006, pp. 119-150.

DOI : $10.1007 / 3-540-32658-8 \_6$

and Lumry 1985). The right part of the Figure 1 shows the residual NH content and the protein adsorption density $(\Gamma)$ recorded over time concomitantly during BSA adsorption on negatively charged hydrophilic (Figure 1A), neutral hydrophilic (Figure 1B) and hydrophobic support (Figure 1C).

On hydrophobic support (Figure 1C), BSA is adsorbed quite fast, within $10 \mathrm{~min}$, while the peptide $\mathrm{NH}$ content decreases drastically to $5 \%$. The larger solvation of the peptide carbonyls induced by adsorption is due to the diffusion of $\mathrm{D}_{2} \mathrm{O}$ molecules into the protein core and is directly correlated with the changes in secondary structure of BSA (Figure 2C). The BSA molecules lose $12 \%$ of its helical domains when they become adsorbed onto the $\mathrm{CH}_{3}$-terminated SAMs while the bent domains remain unchanged. The large unfolding of both the hydrophobic and polar helices involves the increase in the extent in self-associated and hydrated random domains, respectively (Servagent-Noinville et al. 2000). Internal hydrophobic domains of the protein are drafted towards the hydrophobic surface, increasing the solvation of $15 \%$ of the overall polypeptide backbone (Figure 1C). The penetration of $\mathrm{D}_{2} \mathrm{O}$ molecules into the adsorbed proteins is correlated specifically with the increase in the content of the hydrated random domains (Figure 2C). Similar structural transition has been observed for HSA adsorbed on a reversed-phase chromatographic support (Boulkanz et al. 1997).

In contrast with the adsorption on hydrophobic support, the adsorption onto hydrophilic supports leads to weaker adsorbed amounts of BSA. At pH above the isoelectric point, the negatively charged BSA molecules do adsorb on the negatively charged silica surface, but change their solvation states. Indeed the residual NH content of BSA decreases from $20 \%$ to around $5 \%$ as far as the surface coverage is increasing on the negatively charged silica. This change in tertiary structure due to the contact of the protein with the repelling silica surface is also linked to the large unfolding of $\alpha$-helices involving $13 \%$ of the overall peptide carbonyls (Figure 2A).

The adsorption of BSA on the $\mathrm{ND}_{2}$-terminated SAMs is as slow as those on the repelling hydrophilic surface but entails a weaker NH/ND exchange (Figure 1B), which is corroborated to a weaker conformational change of the protein. The adsorption of BSA on the electrostatically neutral support unfolds the most hydrophobic helical domains at 1660 $\mathrm{cm}^{-1}$ involving around $4 \%$ of the overall backbone. The loss in these hydrophobic helical 
Principles and practice : Proteins at solid-liquid interfaces, Springer-Verlag, Berlin Heidelberg 2006, pp. 119-150.

DOI : $10.1007 / 3-540-32658-8 \_6$

domains implies an increase in self-association. The structural change of the homologous HSA adsorbed to a positively charged hydrophilic surface such as an ion-exchanger chromatographic support also entails a small fraction of the overall peptide carbonyls (Pantazaki et al. 1998).

\subsubsection{Adsorption kinetics and conformational changes}

The rates at which BSA was adsorbed onto the three different types of support were measured at a bulk concentration of $500 \mu \mathrm{g} / \mathrm{mL}$ (Figure 1). The adsorbed amounts of BSA $(\Gamma)$ increase with time and reach a plateau after 10 hours for the negatively charged silica (not shown on Figure 1A), after 4 hours for the electrostatically neutral support (Figure 1B) and after $60 \mathrm{~min}$ for the hydrophobic support (Figure 1C).

The adsorbed amount of BSA on the repelling silica surface reaches a value of 0.45 $\mathrm{mg} / \mathrm{m}^{2}$ and $0.7 \mathrm{mg} / \mathrm{m}^{2}$ after 2 and 10 hours, respectively. Under identical conditions of bulk concentration at a $\mathrm{D}_{2} \mathrm{O} /$ silica surface, the adsorbed amount of $\mathrm{BSA}$ determined by specular neutron reflection reached a limiting value of $2.5 \mathrm{mg} / \mathrm{m}^{2}$ at a $\mathrm{pH}$ close to the isoelectric point of the protein but was found to be only $0.5 \mathrm{mg} / \mathrm{m}^{2}$ at $\mathrm{pH} 7$ ( $\mathrm{Su}$ et al. 1998a). The maximum of adsorbed amount of protein molecules is generally observed at the adsorption $\mathrm{pH}$ close to the isoelectric point thanks to the minimization of electrostatic repulsions between the protein and the support (Giacomelli C.E. et al. 1999b; Norde 1998). The structural stability of BSA is known to be strongly pHdependent. The higher content in $\alpha$-helical structure for BSA molecules at the isoelectric point suggests that the molecular shape of BSA is more compact than at higher $\mathrm{pH}$ (Servagent-Noinville et al. 2000). However the negatively charged silica induces a large unfolding of the $\alpha$-helices by attracting the external positively charged Lys (aminium) and Arg (iminium) residues of the BSA molecules, causing the disruption of internal salt bridges between carboxylate side chains and the positively charged residues. Adsorption kinetics of BSA at a bulk concentration of $186 \mu \mathrm{g} / \mathrm{mL}$ on hydrophilic silica-titania surfaces reported by (Kurrat et al. 1997) gave a $\Gamma$ value of 1.3 $\mathrm{mg} / \mathrm{m}^{2}$ in HEPES buffer and a value inferior to $0.1 \mathrm{mg} / \mathrm{m}^{2}$ in phosphate buffer. Another research team found adsorption densities for BSA adsorbed on pure silica reaching 1.4 $\mathrm{mg} / \mathrm{m}^{2}$ at higher bulk concentration of $1800 \mu \mathrm{g} / \mathrm{mL}$ (Kridhasima et al. 1993). It should be pointed out that the limit value of adsorption density depends strongly from the protein concentration (Malmsten 1998). Furthermore the above discrepancy between the 
Principles and practice : Proteins at solid-liquid interfaces, Springer-Verlag, Berlin Heidelberg 2006, pp. 119-150.

DOI : 10.1007/3-540-32658-8_6

reported $\Gamma$ values for BSA could be due not only to the variable charge densities between the various oxide surfaces used in the different works, but also to the influence of counterions on the external charge distribution of the protein and on the protein structure itself.

By assuming that the adsorption plateau corresponds to the formation of a closed-packed monolayer, the average cross-sectional area of the protein adsorbed is calculated and compared to the theoretical values calculated from the molecular dimension of the protein. The calculated cross sectional areas of a BSA molecule adsorbed onto the bare silica and the $\mathrm{CH}_{3}$-terminated SAMs are 155 and $97 \mathrm{~nm}^{2} /$ molecule, respectively. One work also found cross-sectional areas of 99 and $100 \mathrm{~nm}^{2} /$ molecule for BSA adsorbed on hydrophobic polyurethane films at pH 7.0 by the ATR technique (Jeon J.S. et al. 1994). According to the three-dimensional heart-shape of the BSA molecule (Table 1), the cross-sectional area of the native BSA is either 24 or $28 \mathrm{~nm}^{2} /$ molecule depending on an end-on or side-on orientation, respectively. The 5-fold or 4-fold increase in the average cross-sectional area of an adsorbed BSA molecule corresponds to a spreading of the protein either on the repelling hydrophilic or on the hydrophobic support, and is correlated in both cases to the large unfolding of the protein stereoregular structure upon adsorption.

In contrast the average conformation of the adsorbed BSA molecules on the neutral hydrophilic support is unchanged compared to the solvated state (Figure 2B). If the molecular shape of the protein corresponds to that of the native state, the adsorption density of $0.45 \mathrm{mg} / \mathrm{m}^{2}$ obtained on the $\mathrm{ND}_{2}$-terminated SAMs corresponds to the formation of an incomplete or loosely-packed monolayer. This is in agreement with the general findings of poor affinity of proteins towards neutral surfaces (Herrwerth et al. 2003; Ostuni et al. 2001; Silin et al. 1997; Tengvall et al. 1998).

\subsection{Surface-induced conformational changes of a 'hard' protein :}

\section{lysozyme,}

\subsubsection{Changes in solvation due to adsorption}

As illustrated in Figure 3, a first extremely rapid isotopic exchange occurs within the first ten minutes of incubation of lysozyme in the deuterated buffer, corresponding to the exchange in COND of $70 \%$ of the amino acid residues. The residual NH content of 
Principles and practice : Proteins at solid-liquid interfaces, Springer-Verlag, Berlin Heidelberg 2006, pp. 119-150.

DOI : 10.1007/3-540-32658-8_6

lysozyme after 2 hours of incubation reaches $21 \%$ in pure phosphate buffer (Figure 3A, 3C) and $16 \%$ in phosphate buffered saline (Figure 3B). The ionic strength is known to influence the NH/ND isotope exchange kinetics of proteins (Gregory and Lumry 1985).

The adsorption of lysozyme with a positive net charge on the pure silica surface is driven mainly by electrostatic interactions (Robeson and Tilton 1996; Wahlgren M.C. et al. 1993). The adsorbed amounts of lysozyme is increased at low ionic strength as illustarted in Figure $3 \mathrm{~A}$ compared to Figure 3B. The first molecules of lysozyme adsorbed on the negatively charged silica do not change their solvation state since their residual NH content is rather unchanged compared to the equilibrium NH content of the protein in solution. The effect of ionic strength is to limit both the adsorbed amount of lysozyme and the NH/ND exchange of the adsorbed molecules (Figure 2B). Since the diffusion of $\mathrm{D}_{2} \mathrm{O}$ inside the adsorbed molecules of lysozyme is limited, no increase in hydrated random domains is observed (Figure 4A and 4B). The adsorption of the positively charged lysosyme on the silica surface does not induce a significant change neither in solvation nor in secondary structure (Figure 4A and 4B). The more exchanged states of adsorbed lysozyme in phosphate buffer appear when the adsorption density $\Gamma$ exceeds the limit value of $1.25 \mathrm{mg} / \mathrm{m}^{2}$. This limit value of adsorption density could correspond to the adsorption of lysozyme in a side-on orientation, as reported by other groups (Claesson et al. 1995; Wahlgren Marie et al. 1995). The fast adsorption process is considered to form a basal monolayer of lysozyme in native structure, and the slower process could correspond to the multilayer growth. In the second step, the subsequent adsorbed molecules of lysozyme would be more solvated than in the former monolayer (see Figure 3A) although they did not undergo a conformational change on the negatively charged silica. (Ball Vincent and Ramsden 2000) showed that lysozyme exhibits also a two-step adsorption kinetics on a hydrophilic silica-titania surface. Surface apparatus studies of lysozyme adsorbed on mica suggested that lysozyme could exist as a dimer forming a partial bilayer (Blomberg et al. 1998). (Su et al. 1998b) showed that the adsorbed lysozyme on silica retains its tertiary structure and that no significant denaturation occurs. Their results by neutron reflection suggested that the structural arrangement of the adsorbed lysozyme at the aqueous/silica interface is determined by the lateral electrostatic repulsion depending on the jamming within the bilayers and the net charge of the protein at a given pH. From x-ray data, lysozyme is known to have an uneven distribution of the basic and acid residues at its periphery (Wilson et al. 1992). A preferred orientation at low surface 
Principles and practice : Proteins at solid-liquid interfaces, Springer-Verlag, Berlin Heidelberg 2006, pp. 119-150.

DOI : 10.1007/3-540-32658-8_6

coverage would place the external basic residues of lysozyme facing the negatively charged silica surface. Consequently, this preferred orientation decreases the electrostatic repulsion between adjacent protein molecules and maximize the surface attraction, as already suggested by (Haggerty and Lenhoff 1993b).

Many studies have underlined the orientation effect, which could occur during adsorption. When the bulk concentration of protein is low, a side-on orientation of the adsorbed molecules could be favoured. Rather, adsorption at higher bulk concentration could lead to an end-on configuration due to a stronger protein-protein interaction, yielding to a more compact adsorbed layer. Obviously, the presented simplistic calculation from the adsorbed amount does not take into account that in some cases, the jamming coverage could be less than unity (Arai and Norde 1990) and the possibility of coexistence of different orientations of the adsorbed proteins at the interface ( $\mathrm{Su}$ et al. 1998b). For instance, the experimental determinations of the thickness or the lateral distribution by other techniques is necessary to conclude to the formation of incomplete monolayer or to loosely packed monolayer within side-on or end-on orientations are present.

\subsubsection{Adsorption kinetics and conformational changes}

For adsorption on the $\mathrm{CH}_{3}$-terminated SAMs, the adsorption plateau is rapidly reached within 30 min meanwhile the residual $\mathrm{NH}$ content has drastically decreased to a plateau value of $5 \%$. As for BSA adsorbed on hydrophobic support, some $\mathrm{D}_{2} \mathrm{O}$ molecules have penetrated inside the lysozyme core and solvate more amide $\mathrm{CONH}$ bonds because of the changes in secondary structure induced by adsorption (Noinville S. et al. 2002). But the major conformational change concerning lysozyme adsorbed on hydrophobic surface consists in an $\alpha$-helix to $\beta$-sheet structural conversion (Noinville S. et al. 2002; Yokoyama et al. 2003). The maximum adsorbed amount of lysozyme of $0.8 \mathrm{mg} / \mathrm{m}^{2}$ corresponds to the packing of closely molecules with a cross-sectional area of $29 \mathrm{~nm}^{2}$ (Figure 3C). The increase in the cross-sectional area of adsorbed lysozyme could be a consequence of the conformational changes of the molecules requiring a larger area of contact with the hydrophobic surface. The losses of $12 \%$ of peptide carbonyls in helical structure and of $5 \%$ in random hydrated domains give rise to $8 \%$ of $\mathrm{CO}$ in $\beta$-structured domains and 7 $\%$ of CO in self-associated domains (Noinville S. et al. 2002). Since one part of the newly 
Principles and practice : Proteins at solid-liquid interfaces, Springer-Verlag, Berlin Heidelberg 2006, pp. 119-150.

DOI : $10.1007 / 3-540-32658-8 \_6$

formed domains is $\beta$-sheeted, The molecular shape of adsorbed molecules of lysozyme is expected to be less spread than the soft BSA. The lower content in random hydrated domains of the adsorbed lysozyme is linked to the dehydration of the protein/hydrophobic support (Figure 4C). The released peptide carbonyls natively involved in helical structure of lysozyme could not form hydrogen bonds with water molecules no more present at the dehydrated hydrophobic interface. The unfolded peptide carbonyls do form hydrogen bonds involved either in intramolecular domains ( $\beta$-sheets) or in intermolecular self-associated domains. The global structural change in lysozyme caused by adsorption on hydrophobic support is a small loss of stereoregular structures concerning $4 \%$ of the polypeptide backbone against $13 \%$ for the soft BSA (Noinville S. et al. 2002).

\subsection{Folding or unfolding of proteins on hydrophobic supports}

The mainly $\beta$-sheeted serine proteinase such as $\alpha$-chymotrypsin has a high structural stability like lysozyme but undergoes a large unfolding of its $\beta$-sheets upon adsorption on hydrophobic support (Baron et al. 1999; Zoungrana et al. 1997). The released peptide carbonyls form mainly intermolecular hydrogen bonds with neighbouring peptide segments, increasing the self-associated domains in the adsorbed layer of $\alpha$-chymotrypsin (Noinville $S$. et al. 2002). Adsorption on hydrophobic surfaces may result in an increased or decreased order in protein structure whether the balance between the energetically favourable interaction and the conformational entropy is positive or not. For instance another serine enzyme such as Humicola Lanuginosa lipase with a higher overall hydrophobicity than the above proteinase adsorbs on hydrophobic support with a gain in its stereoregular $\alpha / \beta$ fold (Noinville S. et al. 2002). Some antimicrobial peptides known to be random coiled in solution adsorb onto hydrophobic supports by forming amphipathic helices with the hydrophobic external side of the helix oriented towards the support and the polar side to the interfacial solution (Noinville S. et al. 2003). Surface-induced conformational changes of the amyloid $\beta$-peptide were studied by CD spectroscopy on Teflon particles (Giacomelli C. E. and Norde 2003). The authors show that the hydrophobic support promotes the $\alpha$-helix formation at low surface coverage but leads to a more enriched $\beta$-sheeted structure at high surface coverage probably initiating self-aggregation. Even if the extent and the pathways of structural conversion in the case of very flexible polypeptides such as amyloid peptides or prions are still complex to tackle, the effect of the contact with a solid phase is to stabilize 
Principles and practice : Proteins at solid-liquid interfaces, Springer-Verlag, Berlin Heidelberg 2006, pp. 119-150.

DOI : 10.1007/3-540-32658-8_6

adsorbed conformers which could inhibit protein aggregation by the complex interplay of electrostatic and hydrophobic interactions (Revault et al. 2005).

\section{Conclusion}

The initial events of protein adsorption causing solvation or conformational changes can occur at the microsecond to millisecond timescales whereas conformational rearrangement as well as orientation and lateral distribution can occur over much longer time within the layer of adsorbed proteins. As a consequence, the biological function of the immobilized proteins are more or less altered depending on the adsorption history. Combined progresses in structural biology and nanoscale patterned surfaces should lead to a better knowledge of surface-induced conformational changes of proteins determining their enzymatic, cellbinding activities or their recognition or pathogenic functions. 
Principles and practice : Proteins at solid-liquid interfaces, Springer-Verlag, Berlin Heidelberg 2006, pp. 119-150.

DOI : 10.1007/3-540-32658-8_6

\section{References}

Arai I, Norde W (1990) The behavior of some model proteins at solid-liquid interfaces. I, adsorption from single protein solutions. Colloids Surfaces A: Physicochem. Eng. Aspects 51: 1-15.

Asthagiri D, Lenhoff AM (1997) Influence of structural details in modeling electrostatically driven protein adsorption. Langmuir 13: 6761-6768.

Ball A, Jones RAL (1995) Conformational Changes in Adsorbed Proteins. Langmuir 11: 3542-3548.

Ball V, Ramsden JJ (2000) Analysis of hen egg white lysozyme adsorption on Si(Ti)O2 | aqueous solution interfaces at low ionic strength: a biphasic reaction related to solution self-association. Colloids Surfaces B: Biointerfaces 17(2): 81-94.

Banci L, Bertini I, Gray HB, Luchinat C, Reddig T, Rosato A, Turano P (1997) Solution structure of oxidized horse heart cytochrome c. Biochemistry 36(32): 9867-77.

Baron M-H, Revault M, Servagent-Noinville S, Abadie J, Quiquampoix H (1999) Chymotrypsin adsorption on montmorillonite, enzymatic activity and kinetic FTIR structural analysis. J.Colloid Interface Sci. 214: 319-332. Berman HM, Westbrook J, Feng Z, Gilliland G, Bhat TN, Weissig H, Shindyalov IN, Bourne PE (2000) The Protein Data Bank. Nucleic Acids Res 28(1): 235-42.

Billsten P, Carlsson U, Elwing H (1998). Studies on the conformation of adsorbed proteins with the use of nanoparticle technology. (ed) Biopolymers at interfaces. 75. Dekker, New York. 627-650.

Birktoft JJ, Blow DM (1972) Structure of crystalline -chymotrypsin. V. The atomic structure of tosyl- chymotrypsin at 2 A resolution. J Mol Biol 68(2): 187-240.

Blomberg E, Claesson PM, Froberg JC (1998) Surfaces coated with protein layers: a surface force and ESCA study. Biomaterials 19(4-5): 371-86.

Booth V, Waring A, Walther F, Keough K (2004) NMR structures of the C-terminal segment of surfactant protein B in detergent micelles and hexafluoro-2-propanol. Biochemistry 43(48): 15187-94.

Bos MA, Kleijn JM (1995) Determination of the orientation distribution of adsorbed fluorophores using TIRF. I. Theory. Biophys. J. 68(6): 2566-72.

Boulkanz L, Balcar N, Baron M-H (1995) FTIR analysis for structural characterization of Albumin adsorbed on the reversed-phase support RP-C6. Appl. Spectrosc. 49(12): 1737-1746.

Boulkanz L, Vidal-Madjar C, Balcar N, Baron M-H (1997) Adsorption mechanism of Human Serum Albumin on a reversed-phase support by kinetic, chromatographic, and FTIR methods. J.Colloid Interface Sci. 188: 5867.

Branden C, Tooze J (1991) Introduction to protein structure. Garland, New york.

Brash JL (1996) Behavoir of proteins at interfaces. Current Opinion in Colloid Interface Science 1: 682-688.

Buijs J, Norde W, Lichtenberg JWT (1996) Changes in the secondary structure of adsorbed IgG and F(ab') studied by FTIR spectroscopy. Langmuir 12: 1605-1613.

Buijs J, Hlady V (1997) Adsorption Kinetics, Conformation, and Mobility of the Growth Hormone and Lysozyme on Solid Surfaces, Studied with TIRF. J.Colloid Interface Sci. 190: 171-181.

Buijs J, Ramstrom M, Danfelter M, Larsericsdotter H, Hakansson P, Oscarsson S (2003) Localized changes in the structural stability of myoglobin upon adsorption onto silica particles, as studied with hydrogen/deuterium exchange mass spectrometry. J Colloid Interface Sci 263(2): 441-8.

Bujnowski AM, Pitt WG (1998) Water Structure around Enkephalin near a PE Surface: A Molecular Dynamics Study. J.Colloid Interface Sci. 203(1): 47-58.

Byler DM, Susi H (1986) Examination of the secondary structure of proteins by deconvolved FTIR spectra. Biopolymers 25: 469-487.

Carter DC, Ho JX (1994) Structure of serum albumin. Adv. Protein Chem. 45: 155-203.

Chalikian TV, Gindikin VS, Breslauer KJ (1995) Volumetric Characterizations of the Native, Molten Globule and Unfolded States of Cytochrome c at Acidic pH. J. Mol. Biol. 250(2): 291-306.

Cheng S-S, Chittur KK, Sukenik CN, Culp LA, Lewandowska K (1994) The conformation of Fibronectin on SAM with different surface composition: an FTIR/ATR study. J.Colloid Interface Sci. 162: 135-143.

Chirgadze YN, Brazhnikov EV (1974) Intensities and other spectral parameters of infrared amide bands of polypeptides in the $\alpha$-helical forms. Biopolymers 13: 1701-1712.

Chirgadze YN, Fedorov OV, Trushina NP (1975) Estimation of amino acid residue side-chain absorption in the infrared spectra of protein solutions in heavy water. Biopolymers 14: 679-694. 
Principles and practice : Proteins at solid-liquid interfaces, Springer-Verlag, Berlin Heidelberg 2006, pp. 119-150.

DOI : 10.1007/3-540-32658-8_6

Chittur KK, Fink DJ, Leininger RI, Hutson TB (1986) Fourier Transform Infrared Spectroscopy/Attenuated Total Reflection Studies of Protein Adsorption in Flowing Systems: Approaches for Bulk Correction and Compositional Analysis of Adsorbed and Bulk Proteins in Mixtures. J.Colloid Interface Sci. 111: 419-433. Chittur KK (1998) FTIR/ATR for protein adsorption to biomaterial surfaces. Biomaterials 19(4-5): 357-69. Claesson PM, Blomberg E, Froberg JC, Nylander T, Arnebrant T (1995) Protein interactions at solid surfaces. Advances in Colloid and Interface Science 57: 161-227.

deCollongue-Poyet B, Sebille B, Baron M-H (1996) Chromatography of the Interferon $\gamma$ and the Analogue II : FTIR analysis. Biospectroscopy 2: 101-111.

deLozé C, Fillaux F (1972) Spectroscopic study of monosubstituted amides II. rotation isomers in amides substituted by aliphatic side-chain models. Biopolymers 11: 2063-2077.

deLozé C, Baron MH, Fillaux F (1978) Interpretation of the CONH group in solution. Interpretation of the infrared and Raman spectra in relationship to secondary structures of peptides and proteins. J. Chim. Phys. 75: 631-647.

Dill KA, Bromberg S, Yue K, Fiebig KM, Yee DP, Thomas PD, Chan HS (1995) Principles of protein folding-a perspective from simple exact models. Protein Sci 4(4): 561-602.

Dong A, Huang P, Caughey WS (1990) Protein secondary structures in water from second-derivative amide I infrared spectra. Biochemistry 29(13): 3303-8.

Dorsey JD, Dill KA (1989) The molecular mechanism of retention in Reversed-Phase Liquid Chromatography. Chem. Rev. 89: 331-346.

Dousseau F, Pézolet M (1990) Determination of the secondary structure content of proteins in aqueous solutions from their AmideI and Amide II infrared bands. Comparison between classical and partial leastsquares methods. Biochemistry 29: 8771-8779.

Engel MFM, Visser AJWG, van Mierlo CPM (2004) Conformation and orientation of a protein folding intermediate trapped by adsorption. Proc Natl Acad Sci 101(31): 11316-11321.

Fang F, Szleifer I (2001) Kinetics and Thermodynamics of Protein Adsorption: A Generalized Molecular Theoretical Approach. Biophys. J. 80(6): 2568-2589.

Follows D, Holt C, Nylander T, Thomas RK, Tiberg F (2004) Beta-casein adsorption at the silicon oxideaqueous solution interface: calcium ion effects. Biomacromolecules 5(2): 319-25.

Frey S, Tamm. LK (1991) Orientation of melittin in phospholipid bilayers : A polarized attenuated total reflection infrared study. Biophys. J. 60: 922-930.

Fu F-N, Fuller MP, Singh BR (1993) Use of Fourier Transform Infrared/Attenuated Total Reflectance Spectroscopy for the Study of Surface Adsorption of Proteins. Appl.Spectrosc. 47: 98-102.

Gekko K, Hasegawa Y (1986) Compressibility-structure relationship of globular proteins. Biochemistry 25(21): 6563-71.

Giacomelli CE, Bremer MGEG, Norde W (1999a) ATR-FTIR Study of IgG Adsorbed on Different Silica Surfaces. J.Colloid Interface Sci. 220(1): 13-23.

Giacomelli CE, Esplandiu MJ, Ortiz PI, Avena MJ, Pauli CPD (1999b) Ellipsometric study of Bovine Serum Albumin adsorbed onto Ti/TiO2 electrodes. J.Colloid Interface Sci. 218: 404-411.

Giacomelli CE, Norde W (2001) The Adsorption-Desorption Cycle. Reversibility of the BSA-Silica System. J.Colloid Interface Sci. 233(2): 234-240.

Giacomelli CE, Norde W (2003) Influence of hydrophobic Teflon particles on the structure of amyloid betapeptide. Biomacromolecules 4(6): 1719-26.

Gill DS, Roush DJ, Willson RC (1994) J.Colloid Interface Sci. 167: 1.

Gilpin RK (1993) Conformational Changes and molecular dynamics of simple silica immobilized systems. J.

Chromatogr. A. 656: 217-229.

Goormaghtigh E, Cabiaux V, Ruysschaert JM (1994). Determination of soluble and membrane protein structure by Fourier Transform Infrared spectrosocpy I. Assignments and model compounds. In H. J. Hiderson and G. B. Ralston (ed) Subcellular Biochemistry. 23. Plenum Press, New York. 329-362.

Green RJ, Hopkinson I, Jones RAL (1999) Unfolding and intermolecular association in globular proteins adsorbed at interfaces. Langmuir 15: 5102-5110.

Gregory RB, Lumry R (1985) Hydrogen-exchange evidence for distinct structural classes in globular proteins. Biopolymers 24(2): 301-26.

Haggerty L, Lenhoff AM (1993a) STM and AFM in biotechnology. Biotechnol Prog 9(1): 1-11.

Haggerty L, Lenhoff AM (1993b) Analysis of ordered arrays of adsorbed lysozyme by scanning tunneling microscopy. Biophys J 64(3): 886-95.

Haynes CA, Norde W (1995) Structures and stabilities of adsorbed proteins. J.Colloid Interface Sci. 169: 313 328.

Herrwerth S, Eck W, Reinhardt S, Grunze M (2003) factors that determine the protein resistance of oligoether self-assembled monolayers-Internal hydrophobicity, terminal hydrophilicity, and lateral packing density. J. Am Chem Soc 125: 9359-9366. 
Principles and practice : Proteins at solid-liquid interfaces, Springer-Verlag, Berlin Heidelberg 2006, pp. 119-150.

DOI : 10.1007/3-540-32658-8_6

Houbiers MC, Wolfs CJAM, Spruijt RB, Bollen YJM, Hemminga MA, Goormaghtigh EU-hwscsaBTT-NWdaeffecb (2001) Conformation and orientation of the gene 9 minor coat protein of bacteriophage M13 in phospholipid bilayers. Biochim Biophys Acta (Biomembranes) 1511(2): 224-235.

Huyghues-Despointes BM, Pace CN, Englander SW, Scholtz JM (2001) Measuring the conformational stability of a protein by hydrogen exchange. Methods Mol Biol 168: 69-92.

Iwamoto GK, Winterton LC, Stoker RS, Wagenen RAv, Andrade JD, Mosher DF (1985) Fibronectin adsorption detected by interfacial fluorescence. J.Colloid Interface Sci. 106(2): 459-464.

Jeon JS, Sperline RP, Raghavan S (1992) Quantitative analysis of adsorbed serum albumin on segmented polyurethane using FT-IR/ATR spectroscopy. Appl. Spectrosc. 46(11): 1644-1648.

Jeon JS, Raghavan S, Sperline RP (1994) Quantitative analysis of albumin adsorption onto uncoated and poly(ether)urethane-coated ZnSe surfaces using the attenuated total reflection FTIR technique. Colloids Surfaces A: Physicochem. Eng. Aspects 92: 255-265.

Jeon SI, Lee JH, Andrade JD, De Gennes PG (1991) Protein--surface interactions in the presence of polyethylene oxide : I. Simplified theory. J.Colloid Interface Sci. 142(1): 149-158.

Kalnin NN, Baikalov IA, Venyaminov S (1990) Quantitative IR spectrophotometry of peptide compounds in water (H2O) solutions. III. Estimation of the protein secondary structure. Biopolymers 30(13-14): 1273-80.

Karlsson M, Ekeroth J, Elwing H, Carlsson U (2005) Reduction of irreversible protein adsorption on solid surfaces by protein engineering for increased stability. J. Biol. Chem. 280(27):25558-25564.

Kim DT, Blanch HW, Radke CJ (2002) Direct imaging of lysozyme adsorption onto mica by atomic force microscopy. Langmuir 18: 5841-5850.

Kondo A, Oku S, Higashitani K (1991) Structural changes in protein molecules adsorbed on ultrafine silica particles. J.Colloid Interface Sci. 143(1): 214-221.

Kondo A, Urabe T, Yoshinaga K (1996) Adsorption activity and conformation of [alpha]-amylase on various ultrafine silica particles modified with polymer silane coupling agents. Colloids Surfaces A: Physicochem. Eng. Aspects 109: 129-136.

Kondo A, Fukuda H (1998) Effects of adsorption conditions on kinetics of protein adsorption and conformational changes at ultrafine silica particles. J.Colloid Interface Sci. 198: 34-41.

Kridhasima V, Vinaraphong P, McGuire J (1993) Adsorption kinetics and elutability of $\alpha$-Lactalbumin, $\beta$ Casein, $\beta$-Lactoglobulin, and BSA at hydrophobic and hydrophilic interfaces. J.Colloid Interface Sci. 161: 325-334.

Krimm S, Bandekar J (1986) Vibrational spectroscopy and conformation of peptides, polypeptides, and proteins. Adv. Protein Chem. 38: 181-364.

Kurrat R, Ramsden JJ, Prenosil JE (1994) Kinetic model for Serum Albumin adsorption: experimental adsorption. J. Chem. Soc. Faraday Trans. 90(4): 587-590.

Kurrat R, Prenosil JE, Ramsden JJ (1997) Kinetics of Human and Bovine Serum Albumin adsorption at SilicaTitania surfaces. J.Colloid Interface Sci. 185: 1-8.

Lawson DM, Brzozowski AM, Rety S, Verma C, Dodson GG (1994) Probing the nature of substrate binding in Humicola lanuginosa lipase through X-Ray crystallography and intuitive modelling. Protein Eng. 7: 543-550. Lecomte S, Hilleriteau C, Forgerit JP, Revault M, Baron MH, Hildebrandt P, Soulimane T (2001) Structural changes of cytochrome c(552) from Thermus thermophilus adsorbed on anionic and hydrophobic surfaces probed by FTIR and 2D-FTIR spectroscopy. Chembiochem 2(3): 180-9.

Lenk TJ, Ratner BD, Gendreau RM, Chittur KK (1989) IR spectral Changes of bovine serum albumin upon surface adsorption. Journal of Biomedical Materials Research 23: 549-569.

Leonidas DD, Shapiro R, Irons LI, Russo N, Acharya KR (1997) Crystal structures of ribonuclease A complexes with 5'-diphosphoadenosine 3'-phosphate and 5'-diphosphoadenosine 2'-phosphate at $1.7 \mathrm{~A}$ resolution. Biochemistry 36(18): 5578-88.

Lesins V, Ruckenstein E (1989) J.Colloid Interface Sci. 132: 566.

Li L, Chen S, Jiang S (2003) protein adsorption on alkanethiolate self-assembled monolayers: nanoscale surface structural and chemical effects. Langmuir 19: 2974-2982.

Liu S, Haynes C (2005) Energy landscapes for adsorption of a protein-like HP chain as a function of nativestate stability. J Colloid Interface Sci 284(1): 7-13.

Long JR, Shaw WJ, Stayton PS, Drobny GP (2001) Structure and dynamics of hydrated statherin on hydroxyapatite as determined by solid-state NMR. Biochemistry 40(51): 15451-5.

Lu JR, Su TJ, Thirtle PN, Thomas RK, Rennie AR, Cubitt R (1998) The Denaturation of Lysozyme Layers Adsorbed at the Hydrophobic Solid/Liquid Surface Studied by Neutron Reflection. J.Colloid Interface Sci. 206: 212-223.

Lu JR, Perumal S, Zhao X, Miano F, Enea V, Heenan RR, Penfold J (2005) Surface-induced unfolding of Human Lactoferrin. Langmuir 21: 3354-3361.

Lundqvist M, Sethson I, Jonsson B-H (2004) Protein adsorption onto silica nanoparticles: conformational changes depend on the particles'curvature and the protein stability. Langmuir 20: 10639-10647. 
Principles and practice : Proteins at solid-liquid interfaces, Springer-Verlag, Berlin Heidelberg 2006, pp. 119-150.

DOI : 10.1007/3-540-32658-8_6

Malmsten M (1998) Formation of adsorbed protein layers. J.Colloid Interface Sci. 207: 186-199.

Malmsten M, Arnebrant T, Billsten P (2003). Interfacial behavior of protein mutants and variants. In M.

Malmsten (ed) Biopolymers at interfaces. 110. Marcel Dekker, New York. 95-113.

Marchin K, Berrie C (2003) Conformational changes in the plasma protein fibrinogen upon adsorption to graphite and mica investigated by AFM. Langmuir 19: 9883-9888.

Marsh RJ, Jones RAL, Sferrazza M (1999) Neutron reflectivity study of the adsorption of b-Lactoglobulin at a hydrophilic solid/liquid interface. J.Colloid Interface Sci. 218: 347-349.

Martin I, Goormaghtigh E, Ruysschaert J-M (2003) Attenuated total reflection IR spectroscopy as a tool to investigate the orientation and tertiary structure changes in fusion proteins. Biochim Biophys Acta

(Biomembranes) 1614(1): 97-103.

McGuire J, Wahlgren MC, Arnebrant T (1995) Structural stability effects on the adsorption and

dodecyltrimethylammonium bromide-mediated elutability of bacteriophage t4 lysozyme at silica surfaces.

J.Colloid Interface Sci. 170: 182-192.

McNay JL, Fernandez EJ (1999) How does a protein unfold on a reversed-phase liquid chromatography surface? J. Chromatogr. A. 849: 135-148.

Meskers S, Ruysschaert J-M, Goormaghtigh E (1999) H-D exchange of streptavidin and its complex with biotin studied by 2D ATR FTIR spectroscopy. J. Am. Chem. Soc. 121: 5115-5122.

Methot M, Boucher F, Salesse C, Subirade M, Pezolet M (1996) Determination of bacteriorhodopsin orientation in monolayers by infrared spectroscopy. Thin Solid Films 284-285: 627-630.

Mitchell RC, Haris PI, Fallowfield C, Keeling DJ, Chapman D (1988) Fourier transform infrared spectroscopic studies on gastric $\mathrm{H}+/ \mathrm{K}+-\mathrm{ATPase}$. Biochim Biophys Acta 941(1): 31-8.

Mrksich M, Sigal GB, Whitesides GM (1995) Surface plasmon resonance permits in situ measurement of protein adsorption on self-assembled monolayers of alkanethiolates on gold. Langmuir 11: 4383-4385.

Muga A, Mantsch HH, Surewicz WK (1991) Membrane binding induces destabilization of cytochrome c structure. Biochemistry 30(29): 7219-24.

Müller M, Werner C, Grundke K, Eichhorn KJ, Jacobash HJ (1997) ATR-FTIR Spectroscopy of Proteins Adsorbed on Biocompatible Cellulose Films. Mikrochim Acta (supp). 14: 671-674.

Nabet A, Pézolet M (1997) Two dimensional FT-IR spectroscopy: a poxerful method to study the secondary stucture of proteins using H -D exchange. Appl. Spectrosc. 51: 466-469.

Noda I (1989) Two-dimensional infrared spectroscopy. J. Am. Chem. Soc. 111: 8116-8118.

Noinville S, Revault M, Baron M-H, Tiss A, Yapoudjian S, Ivanova M, Verger R (2002) Conformational changes and orientation of Humicola lanuginosa lipase on a solid hydrophobic surface: an in situ interface FTIR-ATR study. Biophys. J. 82: 2709-2719.

Noinville S, Bruston F, Revault M, Baron M-H, Nicolas P (2003) Conformation, orientation and adsorption kinetics of Dermaseptin B2 onto synthetic supports at aqueous/solid interface. Biophys. J. 85: 1196-1206. Noinville V, Vidal-Madjar C, Sébille B (1995) Modeling of protein adsorption on polymer surfaces.

Computation of adsorption potential. J. Phys. Chem. 99: 1516-1522.

Norde W (1998). Driving forces for protein adsorption at solid surfaces. In M. Malmsten (ed) Biopolymers at interfaces. 75. Dekker, New York. 27-54.

Norde W (2000). Proteins at solid surfaces. In A. Baszkin and W. Norde (ed) Physical chemistry of biological interfaces. Marcel Dekker, New York. 115-136.

Ong JL, Chittur KK, Lucas LC (1994) Dissolution/ reprecipitation and protein adsoprtion studies of calcium phosphate coatings by FTIR/ATR techniques. Journal of Biomedical Materials Research 28: 1337-1346.

Oroszlan P, Blanco R, Lu XM, Yarmush D, Karger BL (1990) Intrinsic fluorescence studies of the

kineticsmechanism of unfolding of $\alpha$-lactalbumin on weakly hydrophobic chromatographic surfaces. J.

Chromatogr. 500: 481-502.

Ortega-Vinuesa JL, Tengvall P, Lundstrom I (1998) Aggregation of HSA; IgG; and Fibrinogen on Methylated Silicon Surfaces. J.Colloid Interface Sci. 207: 228-239.

Ostuni E, Chapman RG, Holmlin RE, Takayama S, Whitesides GM (2001) A survey of structure-property relationships of surfaces that resist the adsorption of protein. Langmuir 17: 5605-5620.

Ostuni E, Grzybowski B, Mrksich M, Roberts C, Whitesides G (2003) Adsorption of proteins to hydrophobic sites on mixed self-assembled monolayers. Langmuir 19: 1861-1872.

Pantazaki A, Baron M-H, Revault M, Vidal-Madjar C (1998) Characterization of Human Serum Albumin adsorbed on a porous anion-exchange support. J.Colloid Interface Sci. 207: 324-331.

Patel N, Davies MC, Heaton RJ, Roberts CJ, Tendler SJB, Williams PM (1998) A scanning probe microscopy study of the physisorption and chemisorption of protein molecules onto carboxylate terminated self-assembled monolayers. Appl.Phys.A 66: S569-S574.

Perez E, Proust JE (1987) Forces between mica surfaces covered with adsorbed Mucin across aqueous solution. J.Colloid Interface Sci. 118: 182-191. 
Principles and practice : Proteins at solid-liquid interfaces, Springer-Verlag, Berlin Heidelberg 2006, pp. 119-150.

DOI : $10.1007 / 3-540-32658-8 \_6$

Pike AC, Brew K, Acharya KR (1996) Crystal structures of guinea-pig, goat and bovine alpha-lactalbumin highlight the enhanced conformational flexibility of regions that are significant for its action in lactose synthase. Structure 4(6): 691-703.

Pitt WG, Cooper SL (1986) FTIR-ATR studies of the effect of shear rate upon albumin adsorption onto polyurethaneurea. Biomaterials 7: 340-347.

Prestrelski SJ, Byler DM, Thompson MP (1991) Infrared spectroscopic discrimination between $\alpha$ - and $31_{10^{-}}$ helices in globular proteins. Int. J. Peptide Protein Res. 37: 508-512.

Privalov PL (1979) Stability of proteins: small globular proteins. Adv Protein Chem 33: 167-241.

Qin BY, Bewley MC, Creamer LK, Baker HM, Baker EN, Jameson GB (1998) Structural basis of the Tanford transition of bovine beta-lactoglobulin. Biochemistry 37(40): 14014-23.

Quiquampoix H, Staunton S, Baron M-H, Ratcliffe RG (1993) Interpretation of the pH dependence of protein adsorption on clay mineral surfaces and its relevance to the understanding of extracellular enzyme activity.

Colloids Surfaces A: Physicochem. Eng. Aspects 75: 85-93.

Quiquampoix H, Abadie J, Baron M-H, Leprince F, Matumoto-Pintro PT, Ratcliffe RG, Staunton S (1995).

Mechanisms and consequences of protein adsorption on soil mineral surfaces. (ed) Proteins at interfaces. II.

Fundamentals and Applications. 602, Washington, DC. 321-333.

Radford SE, Buck M, Topping KD, Dobson CM, Evans PA (1992) Hydrogen exchange in native and denatured states of hen egg-white lysozyme. Proteins 14(2): 237-48.

Ramsden JJ (1998). Kinetics of protein adsorption. (ed) Biopolymers at interfaces. 75. Dekker, New York. 321-361.

Read MJ, Burkett SL (2003) Asymmetric [alpha]-helicity loss within a peptide adsorbed onto charged colloidal substrates. J.Colloid Interface Sci. 261(2): 255-263.

Revault M, Quiquampoix H, Baron MH, Noinville S (2005) Fate of prions in soil: trapped conformation of full-length ovine prion protein induced by adsorption on clays. Biochim Biophys Acta 1724(3): 367-74.

Richards FM (1977) Areas, volumes, packing and protein structure. Annu Rev Biophys Bioeng 6: 151-76. Robeson JL, Tilton RD (1996) Spontaneous reconfiguration of adsorbed lysozyme layers observed by Total Internal Reflection Fluorescence with a pH-sensitive fluorophore. Langmuir 12: 6104-6113.

Roth CM, Lenhoff AM (1993) Electrostatic and vander Waals contribution to protein adsorption : computation of equilibrium constants. Langmuir 9: 962-972.

Rothshild KJ, Clark NA (1979) Polarized infrared spectroscopy of oriented purple membrane. Biophys. J. 25: 473-488.

Roush DJ, Gill DS, Willson RC (1994) Electrostatic potentials and electrostatic interaction energies of rat cytochrome b5 and a simulated anion-exchange adsorbent surface. Biophys J 66(5): 1290-300.

Servagent-Noinville S, Revault M, Quiquampoix H, Baron M-H (2000) Conformational changes of BSA induced by adsorption on different clay surfaces : FTIR analysis. J.Colloid Interface Sci. 221: 273-283.

Sharp JS, Forrest JA, Jones RA (2002) Surface denaturation and amyloid fibril formation of insulin at model lipid-water interfaces. Biochemistry 41(52): 15810-9.

Sigal GB, Mrksich M, Whitesides GM (1998) Effect of surface wettability on the adsorption of proteins and detergents. J. Am. Chem. Soc. 120: 3464-3473.

Silin V, Weetall H, Vanderah DJ (1997) SPR studies of the nonspecific adsorption kinetics of Human IgG and BSA on gold surfaces modified by self-assembled monolayers (SAMs). J.Colloid Interface Sci. 185: 94-103.

Soderquist ME, Walton AG (1980) Structural Changes in Proteins Adsorbed on Polymer Surfaces. J.Colloid Interface Sci. 75: 386.

Sokolowski F, Modler AJ, Masuch R, Zirwer D, Baier M, Lutsch G, Moss DA, Gast K, Naumann D (2003)

Formation of critical oligomers is a key event during conformational transition of recombinant syrian hamster prion protein. J Biol Chem 278(42): 40481-92.

Su TJ, Lu JR, Thomas RK, Cui ZF, Penfold J (1998a) The conformational structure of Bovine Serum Albumin layers adsorbed at the silica-water interface. J. Phys. Chem. B. 102: 8100-8108.

Su TJ, Lu JR, Thomas RK, Cui ZF, Penfold J (1998b) The adsorption of Lysozyme at the silica-water interface: a neutron reflection study. J.Colloid Interface Sci. 203: 419-429.

Sukhishvili SA, Granick S (1999) Adsorption of human serum albumin: dependence on molecular architecture of the oppositively charged surface. J. Chem. Phys. 110(20): 10153-10161.

Surewicz WK, Mantsch HH, Chapman D (1993) Determination of protein secondary structure by Fourier transform infrared spectroscopy: a critical assessment. Biochemistry 32(2): 389-94.

Tamm LK, Abildgaard F, Arora A, Blad H, Bushweller JH (2003) Structure, dynamics and function of the outer membrane protein $\mathrm{A}(\mathrm{OmpA})$ and influenza hemagglutinin fusion domain in detergent micelles by solution NMR. FEBS Lett 555(1): 139-43.

Tengvall P, Lundstrom I, Liedberg B (1998) Protein adsorption studies on model organic surfaces: an ellipsometric and infrared spectroscopic approach. Biomaterials 19(4-5): 407-422. 
Principles and practice : Proteins at solid-liquid interfaces, Springer-Verlag, Berlin Heidelberg 2006, pp. 119-150.

DOI : 10.1007/3-540-32658-8_6

Tibbs Jones T, Fernandez EJ (2003) [alpha]-Lactalbumin tertiary structure changes on hydrophobic interaction chromatography surfaces. J.Colloid Interface Sci. 259(1): 27-35.

Tiberg F, Nylander T, Su TJ, Lu JR, Thomas RK (2001) Beta-casein adsorption at the silicon oxide-aqueous solution interface:. Biomacromolecules 2: 844-850.

Tronin A, Edwards AM, Wright WW, Vanderkooi JM, Blasie JK (2002) Orientation Distributions for Cytochrome c on Polar and Nonpolar Interfaces by Total Internal Reflection Fluorescence. Biophys. J. 82(2): 996-1003.

Tsuboi M (1964) Some problems in the infrared spectra of polypeptides and polynucleotides. Biopolymers 1: $527-547$.

van-Straaten J, Peppas NA (1991) ATR-FTIR analysis of protein adsorption on polymeric surfaces. J Biomater Sci Polym Ed 2(2): 113-21.

van der Veen M, Norde W, Stuart MC (2004) Electrostatic interactions in protein adsorption probed by comparing lysozyme and succinylated lysozyme. Colloids Surfaces B: Biointerfaces 35(1): 33-40.

Van Tassel PR, Guemouri L, Ramsden JJ, Tarjus G, Viot P, Talbot J (1998) A Particle-Level Model of Irreversible Protein Adsorption with a Postadsorption Transition. J.Colloid Interface Sci. 207(2): 317-323. Vermeer AWP, Bremer MGEG, Norde W (1998) Structural changes of IgG induced by heat treatment and by adsorption onto a hydrophobic Teflon surface studied by circular dichroism spectroscopy. Biochim. Biophys. Acta 1425(1): 1-12.

Vogler EA (1998) Structure and reactivity of water at biomaterial surfaces. Advances in Colloid and Interface Science 74(1-3): 69-117.

Wadu-Mesthrige K, Amro NA, Liu GY (2000) Immobilization of proteins on self-assembled monolayers. Scanning 22(6): 380-8.

Wahlgren M, Arnebrant T, Lundstrom I (1995) The Adsorption of Lysozyme to Hydrophilic Silicon Oxide Surfaces: Comparison between Experimental Data and Models for Adsorption Kinetics. J.Colloid Interface Sci. 175(2): 506-514.

Wahlgren M, Welin-Klintström S, Karlsson CA-C (1998). Interactions between proteins and surfactants at solid interfaces. (ed) Biopolymers at interfaces. 75. Dekker, New York. 485-512.

Wahlgren MC, Arnebrant T, Paulsson MA (1993) The Adsorption from Solutions of $\beta$-Lactoglobulin Mixed with Lactoferrin or Lysozyme onto Silica and Methylated Silica Surfaces. J.Colloid Interface Sci. 158: 46-53. Wantyghem J, Baron M-H, Picquart M, Lavialle F (1990) Conformational changes of Robinia pseudoacacia Lectin related to modifications of the environment: FTIR investigation. Biochemistry 29: 6600-6609.

Wertz CF, Santore MM (2002) Adsorption and reorientation kinetics of lysozyme on hydrophobic surfaces. Langmuir 18: 1190-1199.

Wilson KP, Malcolm BA, Matthews BW (1992) Structural and thermodynamic analysis of compensating mutations within the core of chicken egg white lysozyme. J Biol Chem 267(15): 10842-9.

Yokoyama Y, Ishiguro R, Maeda H, Mukaiyama M, Kameyama K, Hiramatsu K (2003) Quantitative analysis of protein adsorption on a planar surface by Fourier transform infrared spectroscopy: lysozyme adsorbed on hydrophobic silicon-containing polymer. J Colloid Interface Sci 268(1): 23-32.

Yoon BJ, Lenhoff AM (1992) Computation of the electrostatic interaction energy between a protein and a charged surface. J. Phys. Chem. 96: 3130.

Zhou J, Chen S, Jiang S (2003) Orientation of adsorbed antibodies on charged surfaces by computer simulation based on a united-residue model. Langmuir 19: 3472-3478.

Zoungrana T, Findenegg GH, Norde W (1997) Structure, stability and activity of adsorbed enzymes. J.Colloid Interface Sci. 190: 437-448. 
Principles and practice : Proteins at solid-liquid interfaces, Springer-Verlag, Berlin Heidelberg 2006, pp. 119-150.

DOI : 10.1007/3-540-32658-8_6

\section{FIGURES AND FIGURE CAPTIONS:}

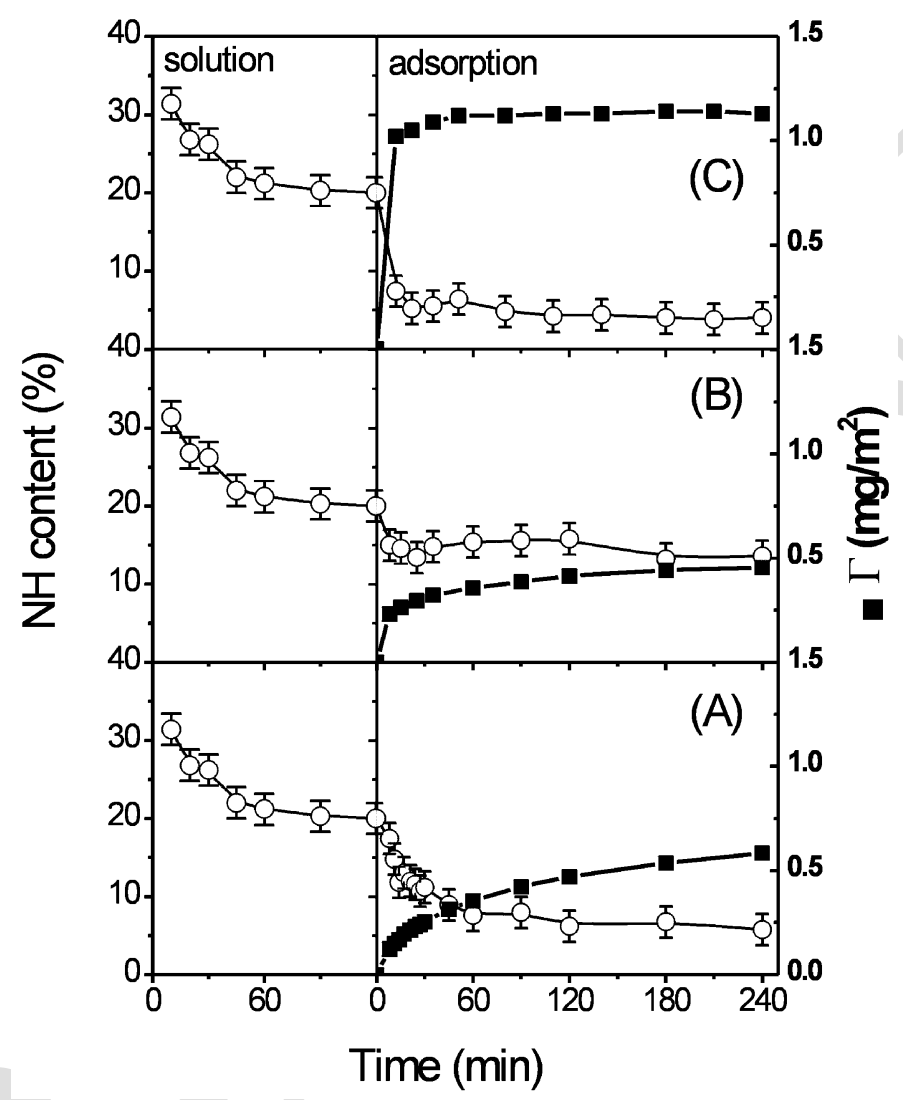

FIGURE 1 : Solvation changes (-O-) and adsorbed amount (-ם-) of Bovine Serum Albumin adsorbed at a bulk concentration of $500 \mu \mathrm{g} / \mathrm{mL}$ in deuterated phosphate buffer and pD 7.5 onto different solid supports : (A) on pure silica surface, (B) on $\mathrm{ND}_{2}$-terminated SAMs, (C) on $\mathrm{CH}_{3}$-terminated SAMs. The left part shows the isotope exchange of the BSA in solution prior to adsorption (right part). The residual $\mathrm{NH}$ content (expressed in percentage of the overall peptide carbonyls) is monitored by the Amide II/Amide I' ratio measurements. The adsorbed amount $(\Gamma)$ of BSA is calculated from the adsorption density equation (Sperline, 1987). 
Principles and practice : Proteins at solid-liquid interfaces, Springer-Verlag, Berlin Heidelberg 2006, pp. 119-150.

DOI : $10.1007 / 3-540-32658-8 \_6$

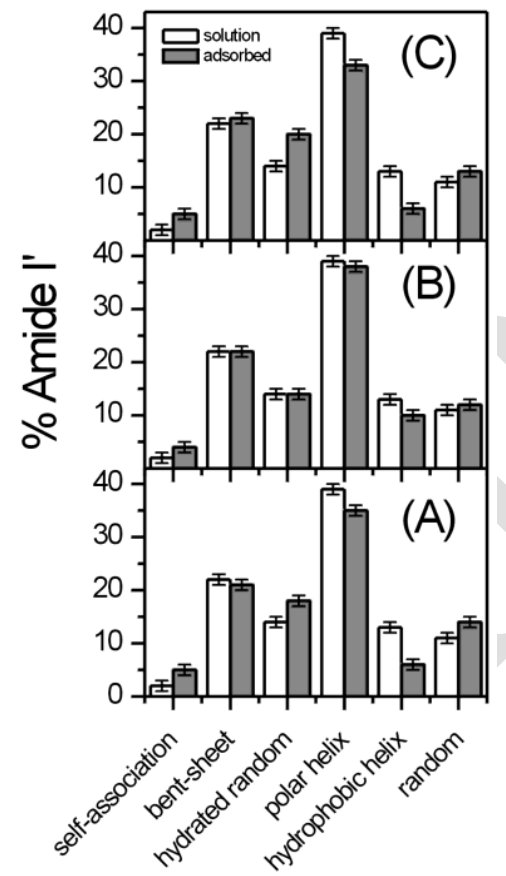

FIGURE 2 : Comparison of secondary structures of BSA resulting from our spectral analysis in deuterated solution and adsorbed at a bulk concentration of $500 \mu \mathrm{g} / \mathrm{mL}$ and $\mathrm{pD}$ 7.5 on different solid supports : (A) on pure silica surface, (B) on $\mathrm{ND}_{2}$-terminated SAMs, (C) on $\mathrm{CH}_{3}$-terminated SAMs. The given \%Amide I' values are recorded at 4 hours in solution and for adsorption. 
Principles and practice : Proteins at solid-liquid interfaces, Springer-Verlag, Berlin Heidelberg 2006, pp. 119-150.

DOI : 10.1007/3-540-32658-8_6

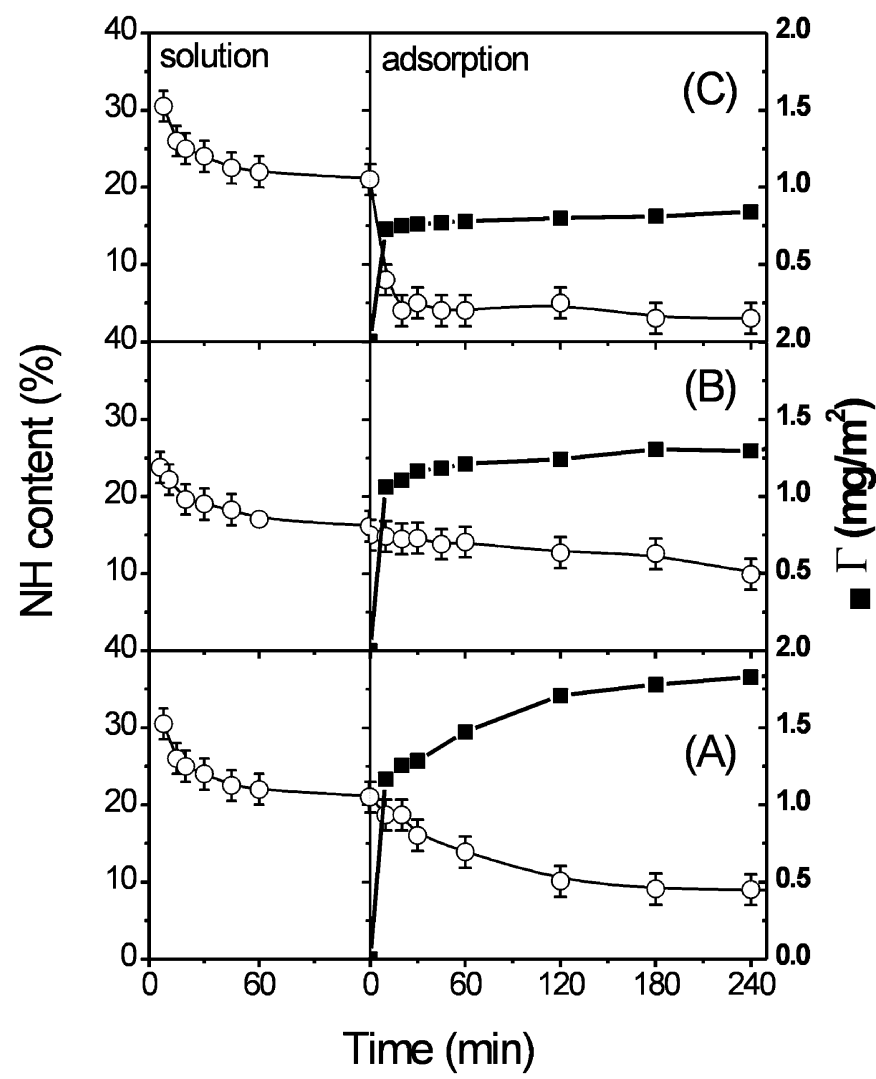

FIGURE 3 : Solvation changes (-O-) and adsorbed amount (-ם-) of lysozyme adsorbed at a concentration of $250 \mu \mathrm{g} / \mathrm{ml}$ and $\mathrm{pD} 7.5$ at different liquid/solid interfaces : (A) deuterated phosphate buffer/pure silica surface, (B) deuterated phosphate buffer with $10 \mathrm{mM} \mathrm{NaCl} /$ pure silica surface, $(\mathrm{C})$ deuterated phosphate buffer/ $\mathrm{CH}_{3}$-terminated SAMs. The residual $\mathrm{NH}$ content (expressed in percentage of the overall peptide carbonyls) is monitored by the Amide II/Amide I' ratio measurements. The adsorbed amount $(\Gamma)$ of lysozyme is calculated from the adsorption density equation (Sperline, 1987). 
Principles and practice : Proteins at solid-liquid interfaces, Springer-Verlag, Berlin Heidelberg 2006, pp. 119-150.

DOI : $10.1007 / 3-540-32658-8 \_6$

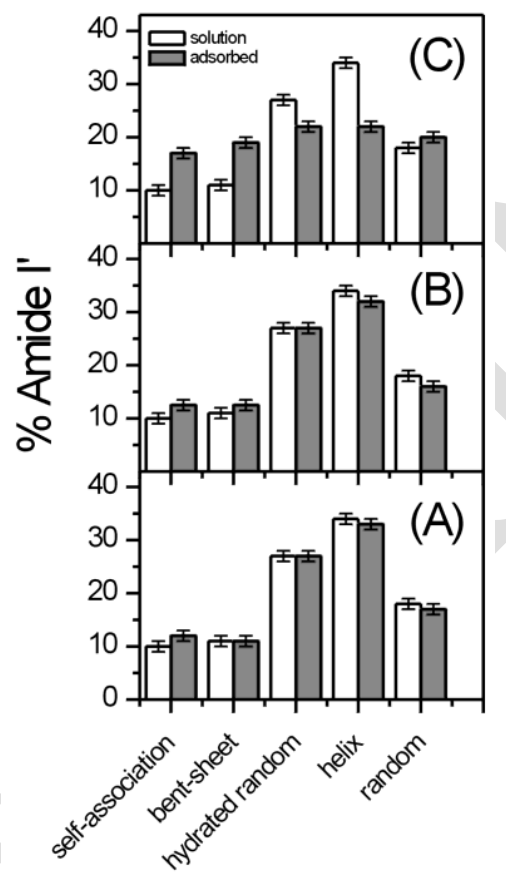

FIGURE 4 : Comparison of secondary structures of lysozyme resulting from our spectral analysis in deuterated solution and adsorbed at a bulk concentration of $250 \mu \mathrm{g} / \mathrm{mL}$ and $\mathrm{pD}$ 7.5 at different liquid/solid interfaces : (A) deuterated phosphate buffer/pure silica surface, (B) deuterated phosphate buffered saline/pure silica surface, (C) deuterated phosphate buffer/ $\mathrm{CH}_{3}$-terminated SAMs. The given \%Amide I' values are recorded at 4 hours in solution and for adsorption, so that corresponds to the maximum adsorbed amount of lysozyme reported in Figure 3. 
Principles and practice : Proteins at solid-liquid interfaces, Springer-Verlag, Berlin Heidelberg 2006, pp. 119-150.

DOI : $10.1007 / 3-540-32658-8 \_6$

Table 1 : Properties of 'soft' proteins

\begin{tabular}{|c|c|c|c|c|}
\hline Property & HSA & BSA & $\beta-\operatorname{Lg}$ & $\alpha-\mathrm{La}$ \\
\hline Molar mass (kD) & 67 & 65 & 18.4 & 14 \\
\hline$\sum \mathrm{Ni}$ & 586 & 582 & 162 & 123 \\
\hline $\operatorname{Dimension}^{(\mathrm{a})}\left(\AA^{3}\right)$ & $30 \times 80 \times 80$ & $30 \times 80 \times 80$ & $36 \times 36 \times 36$ & $37 \times 32 \times 25$ \\
\hline Hydrophobicity $^{(b)}\left(\mathrm{J} \mathrm{g}^{-1}\right)$ & -3.8 & & & -5.8 \\
\hline $\begin{array}{l}10^{10} \text { Compressibility (c) } \\
\left(\mathrm{m}^{2} \cdot \mathrm{N}^{-1}\right)\end{array}$ & 0.712 & 1.05 & 0.845 & 0.827 \\
\hline Isoelectric point & 4.7 & 4.8 & 5.2 & 4.3 \\
\hline Secondary structure $^{(a)}$ & & & & \\
\hline$\% \alpha$-helix & 67 & 67 & 10 & 29 \\
\hline$\% \beta$-sheet & 0 & 0 & 43 & 8 \\
\hline Reference & $\begin{array}{l}\text { (Carter and } \\
\text { Ho 1994) }\end{array}$ & $\begin{array}{l}\text { (Carter and } \\
\text { Ho 1994) }\end{array}$ & $\begin{array}{c}\text { (Qin et al. } \\
\text { 1998) }\end{array}$ & $\begin{array}{c}\text { (Pike et al. } \\
\text { 1996) }\end{array}$ \\
\hline PDB entry (d) & $1 \mathrm{BMO}$ & & 3BLG & $1 \mathrm{HFX}$ \\
\hline
\end{tabular}
et al. 2000) 
Principles and practice : Proteins at solid-liquid interfaces, Springer-Verlag, Berlin Heidelberg 2006, pp. 119-150.

DOI : $10.1007 / 3-540-32658-8 \_6$

Table 2 : properties of 'hard' proteins

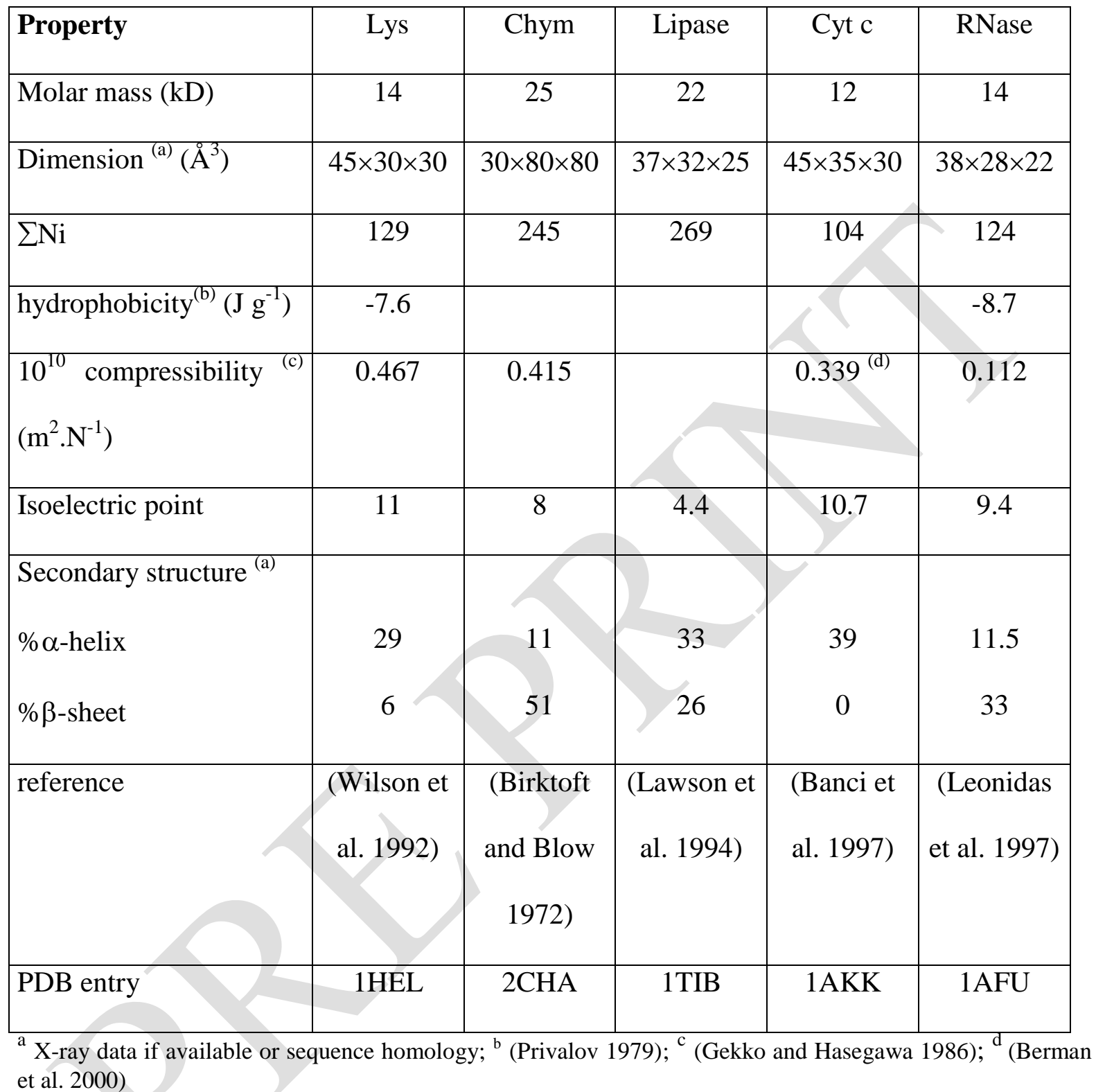


Principles and practice : Proteins at solid-liquid interfaces, Springer-Verlag, Berlin Heidelberg 2006, pp. 119-150.

DOI : $10.1007 / 3-540-32658-8 \_6$

Table 3 : Assignments of the Amide I' components and extent in secondary structure elements (expressed in \% of overall Amide I' area) of BSA and Lysozyme incubated for 4 hours in deuterated phosphate buffer at pD 7.5.

\begin{tabular}{|c|c|c|c|c|}
\hline \multirow{2}{*}{$\begin{array}{l}\text { Assignments to } v(\mathrm{CO}) \\
\text { peptide carbonyls }\end{array}$} & \multicolumn{2}{|c|}{ BSA } & \multicolumn{2}{|c|}{ Lysozyme } \\
\hline & $\begin{array}{c}\text { Wavenumber } \\
\left(\mathrm{cm}^{-1}\right)\end{array}$ & $\begin{array}{l}\text { Area } \\
(\%)\end{array}$ & $\begin{array}{c}\text { Wavenumber } \\
\left(\mathrm{cm}^{-1}\right)\end{array}$ & $\begin{array}{l}\text { Area } \\
(\%)\end{array}$ \\
\hline random domains & 1681 & 12 & & 18 \\
\hline random domains & 1671 & & & 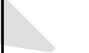 \\
\hline hydrophobic $\alpha$-helices & 1660 & 14 & & - \\
\hline$\alpha$-helices & 1651 & 39 & 1652 & 34 \\
\hline hydrated random domains & 1640 & 13 & 1641 & 27 \\
\hline bent, $\beta$-strands or $\beta$-sheets & 1630 & 23 & 1630 & 11 \\
\hline self-association & 1612 & 2 & 1610 & 10 \\
\hline Reference & $\begin{array}{l}\text { (Servagent-No } \\
\text { al. 2000) }\end{array}$ & ille et & $\begin{array}{l}\text { (Noinville S. e } \\
\text { 2002) }\end{array}$ & \\
\hline
\end{tabular}

